DEPARTMENT OF ECONOMICS WORKING PAPER SERIES

Portrait of the Economist as a Young Man:

Raúl Prebisch's evolving views on the business cycle and money, 1919-1949

\author{
Esteban Pérez Caldentey \\ Matías Vernengo
}

Working Paper No: 2011-13

\author{
University of Utah \\ Department of Economics \\ 260 S. Central Campus Dr., Rm. 343 \\ Tel: (801) 581-7481 \\ Fax: (801) 585-5649 \\ http://www.econ.utah.edu
}




\title{
Portrait of the Economist as a Young Man: Raúl Prebisch's evolving views on the business cycle and money, 1919-1949
}

\author{
Esteban Pérez Caldentey \\ Economic Commission for Latin America and the Caribbean \\ esteban.perez@eclac.org \\ Matías Vernengo \\ University of Utah \\ vernengo@economics.utah.edu
}

\begin{abstract}
This paper analyzes Raúl Prebisch's less familiar contributions to economic theory, related to the business cycle, and heavily informed by the Argentinean experience. His views of the cycle emphasize the common nature of the cycle in the center and the periphery as one unified phenomenon. While his rejection of orthodoxy is less than complete, some elements of what would become a more Keynesian position are developed. In particular, a preoccupation with the management of the balance of payments and the need for capital controls as a macroeconomic management tool, considerably before Keynes and White's plans led to the Bretton Woods agreement. In the process it is clear that Prebisch developed several ideas that are still relevant to understand cyclical fluctuations in the periphery, and became more concerned with the capacity of taking advantage of cyclical booms to maintain sustained economic growth.
\end{abstract}

Keywords: Business Cycle, Macroeconomic Policy, History of Economic Thought JEL Classification: B31, E32, E65

Acknowledgements: The authors are Economic Affairs Officer at ECLAC (Santiago, Chile) and Associate Professor of Economics (University of Utah). The opinions here expressed are the authors' own and may not coincide with that of the institutions with which they are affiliated. The authors wish to express their gratitude to Benjamin Hopenhaym, Member of the Fenix Plan and former collaborator of Raúl Prebisch; and to Mario Rapoport and Noemí Brenta, Director and Researcher of the Institute of Research of Economic and Social History of the Faculty of Economic Science of the University of Buenos Aires for their valuable comments to an earlier version presented on the $10^{\text {th }}$ of December 2010 at the Center of Economics and Finance for the Development of Argentina (CEFID-AR). The authors also wish to thank Emiliano Libman for a useful exchange of viewpoints on the role played by the Bank of England and the Federal Reserve Bank of New York in determining fluctuations of the Argentinean economic cycle. All English translations of sources in French and in Spanish including Prebisch's Works (Vols. I to IV) are by the authors of this paper. Brackets in quotes were introduced by the authors. Throughout the text Prebisch's Works are cited as RP with the respective volume and page(s) numbers. 


\section{Introduction}

Raúl Prebisch (1901-1986) is mostly known for his long-run analysis and diagnostic of the development problem of Latin America which he fully stated in "The Economic Development of Latin America and Some of its Principal Problems", (1949 [1950]), also known as Prebisch's 'Manifesto,' and in 'Growth, Disequilibrium and Disparities: Interpretation of the Process of Economic Development" (1950). At the same time a major concern, expressed in previous writings and more particularly during the period 1919-1949 was the fluctuations of the business cycle and its relationship to money and finance, to a great extent, a direct result of his experience with the management of the Argentine economy.

His interest in the business cycle was inspired by the frequent and severe fluctuations experienced by the Argentine economy in both the $\mathrm{XIX}^{\text {th }}$ and $\mathrm{XX}^{\text {th }}$ centuries. While the episodes he analyzes $(1822 ; 1867-1880 ; 1881-1886 ; 1886-1891 ; 1899-1914$; 1927-1933, 1935-1937, 1939-1944) are very specific to their particular historical context, he argued that they were in their majority examples of a more generic type of cycle, a 'boom and bust cycle.'

According to Prebisch cycles were 'natural', 'recurrent' and inevitable facts of economic life. Moreover, he argued that the cycle phases were related. The sharpness of the contractionary phase was directly related to the excesses of the expansionary phase. Initially he held a monetary view of the cycle akin to that of Hawtrey, where financial flows played a crucial role as a triggering factor. In his analysis of the cycle he highlighted the role of expectations and speculation in ways, which are reminiscent of modern analyses of financial crises that was typical of the Scandinavian school of the time. $^{2}$

\footnotetext{
${ }^{1}$ It is in this sense that we refer throughout the paper to these periods as Prebisch cycles. Prebisch's analysis starts with 1822, the year of establishment of the first bank in Argentina. During the period covered in this paper, Prebisch held various posts in government and academia. He acted as head of the statistical unit of the Argentinean Rural Society in 1922 and later on in 1928 as advisor. He was professor of Economic Policy at the Faculty of Economic Sciences of the National University of Buenos Aires (19241948); deputy director of the Argentine Department of Statistics (1925 to 1927); director of economic research for the National Bank of Argentina (1927 to 1930); under-secretary of finance (1930 to 1932); advisor to the Ministries of Agriculture and Finance; and in 1935 he became the first Governor of the Central Bank of Argentina until 1943. See Dosman (2008).

${ }^{2}$ On the role of Scandinavian, or Swedish, school, in particular its preoccupation with expectations and macroeconomic dynamics see Leijonhufvud (1981). Hawtrey and other Cambridge economists, like Keynes and Robertson, emphasized monetary shocks, in contrast to Wicksell and Schumpeter, which emphasized the role of real shocks as central for the trade cycle. Hawtrey worked at the Treasury, but was educated at Cambridge and was seen as a peripheral member of the same school of thought. On Cambridge monetary ideas at that time see Bridel (1987).
} 
Eventually under the influence of the Great Depression he assigned a more prominent place to exports and external demand. This led him to introduce an antecedent to the Prebisch-Singer declining terms-of-trade hypothesis. At the same time, he provided an early development of Harrod's foreign trade multiplier, which highlighted the Balance-of-Payments constraint to economic growth in developing countries. ${ }^{3}$

A key component of his analysis of the cycle was to devise a policy strategy to extract the 'boom' and 'bust' character of the cycle. Prebisch sought that the creation of a Central Bank could indeed perform this task. Eventually he came to realize that a Central Monetary Authority could even go further and actually mitigate the amplitude of the fluctuation in the business cycle. These views not only led him to play an instrumental role in the creation of the Argentine Central Bank but also to introduce and recommend counter-cyclical economic policy actions including the undertaking of public works and infrastructure, the financing of industry, and the introduction of foreign exchange and capital controls, a discussion that preceded Keynes and White defense of capital controls at Bretton Woods. As part of his policy recommendations, and in consonance with current day views, Prebisch also favored international reserve accumulation as a precautionary measure to weather downturns.

Eventually after having concentrated mainly in devising policies for mitigating economic contractions in Argentina, Prebisch's attention turned, during and following WWII, towards taking advantage of the upward conditions of the cycle to achieve improved and sustained rates of growth. This led him to focus on the problem of economic growth in general, as he termed it, highlighting and underscoring the need to capture the required domestic policy space and autonomy to isolate, as much as possible, the national economy from the fluctuations of developed countries. Central to this viewpoint was the substitution of domestic for foreign production through the promotion of local industry.

These ideas, jointly with the recognition that the observed economic cycle constituted a realization of a single global process, rather than a country specific phenomenon, whose impulses triggered by the cyclical center (first Great Britain and then the United States) were transmitted to the countries of the periphery (including Latin America), paved the way for the development of his later conceptual framework articulated in the 'Development Manifesto' and in 'Growth, Disequilibrium and Disparities. $^{, 4}$

This paper traces, analyzes and interprets critically Prebisch's evolving views on the cycle and on money and highlights their current relevance, in face of changing economic circumstances. Most of the focus is placed on the cycles prior to WWII.

\footnotetext{
${ }^{3}$ In this paper we follow McCombie and Thirlwall (1994) approach to the Balance-of-Payments Constraint.

${ }^{4}$ The Economic Development of Latin America and Some of its Principal Problems or the Prebisch 'Manifesto' was published in 1949 as an introduction to the 1948 Economic Survey of Latin America and also appeared in the same year in The Revista Brasileira de Economia, No.3, pp. 47-109 and in El Trimestre Económico 16(63); 347-431, July-September and in 1950, in Revista de Ciencias Económicas, Buenos Aires, año 38, Serie III, No.22, March-April. In 1962 it appeared in the Boletín Económico de la América Latina, Vol. III, núm.1, February 1962. "Growth, Disequilibrium and Disparities: Interpretation of the Economic Development Process" constituted the first part of the 1949 Economic Survey of Latin America.
} 
The article shows how Prebisch, starting with a very orthodox economic theory, was led by the force of events to partially change and adopt alternative views. However, his rejection with standard mainstream theory or what Prebisch in his writings calls 'orthodox theory' was far from complete. In general, throughout the period under study Prebisch remained committed to fiscal orthodoxy.

Yet, it is clear that he did incorporate and developed elements of what would be Keynesian theory, adapted to the context of peripheral countries. In addition, the article argues that Prebisch thinking was very much in line with the current trend of economics at the time and in some instances was plainly at the forefront of economic thought as exemplified by his influence on Robert Triffin's thinking on Central Banking issues.

The paper is divided into seven sections. The first presents Prebisch's typification of the Argentinean cycle. The second, third and fourth sections examine within Prebisch's thinking the initiating factors of the cycle, the change from boom (expansionary phase) to bust (contractionary phase) conditions and the transmission mechanism in both phases. The fifth section centers on Prebisch's views on the foreign trade multiplier and its role in the business cycle. Finally, sections six and seven analyze Prebisch's changing views on monetary policy during the cycle and more generally those pertaining to policy autonomy. These also discuss the evolution of his conception of the cycle from a country specific phenomenon to that of a single universal process.

\section{Prebisch's typification of the Argentinean business cycle}

According to Prebisch, boom and bust cycles were a pervasive feature of Argentina's economic history. In the writings analyzed in this paper covering the period from 1820 to 1944 , he identified and analyzed, albeit not with the same depth and detail, eight business cycles, the majority of which took place under a regime of convertibility. ${ }^{5}$ Their time span and comparison with other authors for the period Prebisch studied is shown below in Table 1. A more detailed depiction is provided in Table 8 in the annex describing the main features of the monetary regimes associated with each of the Prebisch cycles.

\begin{tabular}{|c|c|c|c|c|c|}
\hline \multicolumn{6}{|c|}{ Table 1 Cycles in Argentina: 1820-1944: A comparison of different authors } \\
\hline Prebisch & $\begin{array}{c}\text { Diaz- } \\
\text { Alejandro }\end{array}$ & Ferrer & Cortes-Conde & $\begin{array}{l}\text { Di Tella \& } \\
\text { Zymelman }\end{array}$ & Sanz-Villarroya \\
\hline 1820 to 1826 & $1900-1904$ to & 1910 to 1914 & 1875 to 1912 & 1876 to 1885 & 1875 to 1880 \\
\hline 1867 to 1880 & 1910-1914 & 1914 to 1929 & 1912 to 1927 & 1885 to 1892 & 1881 to 1902 \\
\hline 1881 to 1885 & & 1930 to 1950 & 1927-to 1947 & 1892 to 1902 & 1903 to 1918 \\
\hline 1886 to 1891 & $1910-1914$ to & & & 1902 to 1908 & 1919 to 1932 \\
\hline $1899(1903)$ to & $1925-1929$ & & & 1908 to 1914 & 1933 to 1952 \\
\hline 1914 & & & & 1914 to 1917 & \\
\hline 1927 to 1933 & $1925-1925$ to & & & 1917 to 1922 & \\
\hline 1935 to 1937 & 1941-1943 & & & 1922 to 1926 & \\
\hline 1939-1944 & & & & 1926 to 1933 & \\
\hline & $1941-1943$ to & & & 1933 to 1938 & \\
\hline & 1953-1955 & & & 1938 to 1945 & \\
\hline
\end{tabular}

\footnotetext{
${ }^{5}$ See, Cortés Conde (2001), Gurrieri (2001), Mallorquin (2006; 2007) and O’Connell (2001) for analyses covering, with differing degrees of detail and depth, Prebisch's thinking on business cycles and monetary issues.
} 
\& Zymelman (1973); Cerro (2008) also provides a recent attempt to date and define the amplitude and duration of Argentine cycles starting in 1822 and ending in 1995 on a quarterly and time continuous basis.

Prebisch perceived cycles, for the most part, as by other economists at the time, as recurrent and inevitable facts of economic life, or more precisely as 'natural' economic phenomena. Cycles were by definition generic with symmetric and necessarily continuing upward and downward phases and independent of historical time and space. Moreover, the intensity of the bust (downward phase) was dependent on the excesses of the boom (upward phase). ${ }^{6}$

The regularity of their occurrence and movement, and their lack of specificity and historical contingency held sway in Prebisch's thinking even until the start of the Great Depression. As he put it (RP, Vol. I, p. 618):

"...it is thus evident, the cyclical character of the disturbances with which the year 1929 end and with which begins the current year [1930]. It is a short-term phenomenon; a period of descent of the ondulatory movement that characterizes normally the evolution of any country; it is a superficial fact; that by itself does not affect the economic structure of the national economy, nor that carries significant deviations in the persistent ascending direction of its economic activities." $^{, 7}$

Cycles, their phases and turning points, were mainly driven by external factors including the conditions in international liquidity and financial markets. While throughout his writings he presents examples of the effects of internal monetary expansion on the economy, he did not believe that the cycle was generated by domestic factors. As he put it (RP, Vol. III, p. 371): "I have not observed, neither in the cycles I

\footnotetext{
${ }^{6}$ This view is made explicit in Pareto's Cours D'Économie Politique (1896-1897) with which Prebisch was familiar. Pareto (1897, Vol. II, pp. 277-297), also believed that the term crisis should apply to both the boom and bust (expansion and contraction), that is to the complete cycle and Prebisch was in agreement (Vol. I, p. 118, note 54). The following quote by Pareto (1897, Vol. II, p.278) encapsulates both ideas: "In truth of the matter we reserve the most often this term [crisis] for the descending period of the oscillation, when prices fall, but in reality, this period is narrowly linked to the ascending period, when prices increase.; the former cannot subsist without the latter, and it is to their ensemble for which should be reserved the term crisis."

${ }^{7}$ The events of the year 1929 were viewed as a further extension of the 1927-1928 cycle. Initially he dated the ascending phase of the cycle between May 1927 and September 1928 (RP, Vol, I. p. 587). Later on however, once the effects of the year 1929 were visible in the Argentine economy he states that the descending phase of the cycle started during 1929 with some symptoms appearing by the middle of 1928 (Ibid. p.613). This point is also emphasized in his 1934 article The Present Moment of Our Economy. He states (RP, Vol. II., p. 158): "If we were to judge the year 1933...by the evolution of our agricultural exports, we would only be able to say that it was an additional year of contraction adding to those that have ...the Argentine economy since 1929." Prebisch came to realize the distinct character of the Great Depression when he became aware of the profound contraction in agricultural prices. The contraction was so sharp that the agricultural price index reached levels that it had not witnessed since the nineteenth century. As he put it (Ibid., p.346-347 and also 135): "The collapse in prices...does not constitute the usual phenomenon of cyclical reaction...rather an intense and pertinent decline to positions each time farther away from the level on which developed the relations of production and credit." And (p. 135) "It [the decline in agricultural prices] is not a simple return to a previous situation, but of an accentuated and progressive contraction of values, that violently upsets the economic structure of the country."
} 
have seen closely nor in those that I have studies in our history, the existence of domestic elements with the sufficient force to promote, by itself, our wave motion."

The fact that the cycle was generated by exogenous factors marked for Prebisch, at this stage of his thinking, a fundamental difference between the theories put forward to explain the cycle in a primary product exporter such as Argentina and those that sought to explain the cycle in the larger industrialized countries.

Yet, in fact, he tenaciously held on to a monetary theory, and even to a pure monetary theory, of the trade cycle throughout his writings, conceptually articulated around the quantity theory of money and the circulation velocity of money, concepts which in fact were was also used to explain the cycle in the more developed countries. In this regard, besides the influences of Argentinean figures such as, Norberto Piñero ${ }^{8}$ and Juan B. Justo, ${ }^{9}$ or Luis Roque Gondra, ${ }^{10}$ the cycle analysis of Prebisch bore the visible

\footnotetext{
${ }^{8}$ Norberto Piñero was minister of finance of Argentina twice from March to September 1906 and from April to July 1913 under the presidencies of José Figueroa Alcorta (1906-1910) and Roque Saenz Peña (1910-1914) respectively. He also held the Chair of Banking at the Faculty of Economic Science and Prebisch studied under him (See Caravaca and Plotkin, 2007). In 1921, Piñero published the book, Money, Credit and Banks in Argentina whose aim was to study the current problems of the time in Money and Banking in light of the teachings of the past. The critical reading of the book by Prebisch prompted him to write "Annotations to our circulating media" (1921) (RP, Vol. I. pp.93-175, through which in fact he provided a monetary and financial history of Argentina from the establishment of the first bank in 1822 to the demise of the 1899 Conversion Caisse experiment in 1914. Prebisch was critical of the book. Prebisch thought that on the one hand Argentine economists and money and banking scholars, described events with an 'overwhelming static objectivity,' they had frequently ignored the most important ones focusing instead on the superficial ones. Moreover their explanation of events was based on fortuity and contingency. On the other hand, they were attracted to the study of the judicial character of institutions and the monotonous exegesis of laws and decrees whose influence was highly questionable and to the research of the intention of the legislator rather than the inquiry of reality' (RP, Vol. I., p. 94). Prebisch thought that Piñero's book did not fill the existing vacuum although he did praise Piñero for avoiding originality (or the ideas of monetary cranks) in his study of present day problems. In a later interview in 1983, he termed the book 'an intellectual disaster' (see, Mallorquin, 2006, p.8)). In his Annotations (p.95), he states that the works of J.H Williams ([1920] (1969) and E. Lorini (1902) 'opened up a new horizon on our monetary problems and indicated the method to follow in their study.' (this even though he later claimed that Williams was in his book 'disconcerted but with very penetrating observations' (Mallorquin, op.cit.)). Williams was part of the Harvard School and a disciple of Frank Taussig, and thus a follower of the quantity theory of money and orthodox monetary views as was Piñero and even Prebisch himself in his annotations. The differences with Piñero may have been overstated and may not have been of substance as both Prebisch, at this stage, and Piñero shared the same theoretical framework, a framework acquired by Prebisch, probably, in part from the lectures of Piñero himself.

${ }^{9}$ Juan B. Justo (1865-1925) was a multidimensional intellectual (medical doctor, journalist a member of parliament, writer on different topics including money) who founded the Argentina Socialist Party and translated into Spanish the first volume of Karl Marx's Das Kapital (Portantiero, 1999). He was nonetheless at the same time a believer in Free Trade and in the Gold Standard and in 'sound money.' As he put it: "Sound gold money or convertible paper money convertible at par must be a postulate of the international working class, especially in countries such as those of South America, where the debasement of the currency is one of the preferred ways to intensify the exploitation of the worker." In a speech to the Chamber of Deputies in 1913 (September, 24), he praised the establishment of the 1899 Conversion Caisse, for restoring monetary normality. Justo published a Tract on monetary issues ((Money, (La Moneda)) in 1903. Prebisch attended Justo's lectures at the university and became a supporter and admirer of Justo's ideas including those related to the Gold Standard and Free Trade until the Great Depression. In 1919, Prebisch read Justo's translation of Marx's first volume of Capital. He praised Justo's Tract of Money and
} 
and notorious stamp of Irving Fisher (1911), Ralph Hawtrey ([1919], 1950), Frank Taussig ([1911], 1917, 1927), Vilfredo Pareto (1896-1897) and also Clément Juglar (1862). ${ }^{11}$

In consonance with this approach Prebisch gave predominance to "changes in the flow of money' as the main cause of business cycle fluctuations. ${ }^{12}$ At first he placed the emphasis on financial flows, determined on the demand side by Argentina's financing needs and on the supply side by the liquidity stance of developed countries (Great Britain and the United States), as the triggering factor leading to a subsequent expansion of liquidity, prices and the improvement in business outlook and conditions. In so doing, he underscored what he termed to be the 'subjective factors' of the cycle such as speculation, business expectations, euphoria and contagion as important factors in maintaining the momentum of the boom (expansionary phase) very much in line with a Kindleberger \& Aliber ([1978] 2005; 1984) type explanation 'avant la lettre. ${ }^{13}$

thought it 'a required reading for those interested in the monetary problems of Argentina' (See, "Studies on Money. J.B. Justo. Third Edition. Buenos Aires.1921”. Reproduced in RP, Vol.I. pp. 55-60).

${ }^{10}$ Luis Roque Gondra (1881-1946) taught economics at the Faculty of Economics Science of the University of Buenos Aires (1913) and became full professor in 1922. He was influenced by Pareto, the Italian marginalists such as Maffeo Pantaleoni (1857-1924) and Enrico Barone (1859-1924) and the Lausanne School. In 1917 he translated Pantaleoni's book Pure Economics (1889) and taught the first course on mathematical economics in Argentina in 1918. In 1933 he published his Elements of Political Economy. His teaching shaped Prebisch's favorable views of Pareto and other Italian neo-classical economists. Prebisch translated the first Spanish version of Barone's Principles (1908), initially assigned to Mauricio Nierentsein (1877-1937), which appeared in 1926. The translation was revised and extended by Gondra and a second version appeared in 1931 failing to mention Prebisch and Nierenstein (Fernández-López 2002, Prebisch, 1986). Prebisch considered Nierenstein as very influential in shaping his thought although did not provide details. He was a man of vast culture and learning, though not an economist by profession. He held the position of professor of Political Economy at the Faculty of Economics Science of the University of Buenos Aires in the 1920's. He was also the university's administrative secretary. Both Gondra and Nierenstein proposed Prebisch as Associate Professor in 1923.

11 By the time he wrote his Annotations, Prebisch was well acquainted with the North American and European economic literature on the cycle. He possessed a detailed knowledge of some of Fisher's work including the Purchasing Power of Money (1911) and Stabilizing the Dollar (1920) (See, RP, Vol. I, pp.1417, and pp. 116-127). His mentor Alejandro Bunge had been in contact with Fisher regarding index numbers (Imaz, 1974). Prebisch attributed a strong influence to Taussig's works including his Economic Principles ([1911], 1915; See RP, Vol. I p.181, Ibid.) and his trade theory, as attested by his continuous references to Williams (a Taussig disciple), whose book on Argentina Prebisch translated into Spanish in 1922, and also by Prebisch's own remarks on Taussig (Pollock at Al., 2002, p.537). He had also read Tugan-Baranowsky,([1894], 1912) and the Italian marginalists authors (Prebisch learned to read Italian in secondary school), and adopted Pareto's (1897) definition of crisis (see footnote 6 above). Finally his arguments in favor of liquidation as a necessary stage of the cycle (see footnotes 37 and 38) are too close to those of Juglar's (1860) theory to ignore that influence even if it came from indirect or secondary sources. Cortés Conde (2001) mentions in passim the influence of Hawtrey's 1919 Currency and Credit in Prebisch's early thinking.

${ }^{12}$ Haberler (1952, p. 15) characterizes the purely monetary explanation of the business cycle as one in which "changes in the flow of money are the sole and sufficient cause of changes in economic activity, of the alteration of prosperity and depression." In Prebisch as will be obvious, changes in the flow of money occur through external sector changes, variations in financial flows and export revenue.

13 Also note that at the time Prebisch introduced distinguished between the objective and subjective elements of the cycle, expectations was part and parcel of the explanation of the trade cycle in Cambridge (England). One year after Prebisch wrote his 'Annotations of our own circulating medium (1921), Lavington published the first edition of his trade cycle, where confidence, anticipations and contagion played an essential role. 
Following the dip in agricultural prices provoked by the Great Depression, which led Prebisch to formulate an antecedent of the Prebisch-Singer hypothesis, his attention shifted to export variations as the initiating cause of economic fluctuations. Even though, the perturbations originated in real factors such as the terms-of-trade and external aggregate demand, the consequent changes in the flow of money, expenditure and the circulation velocity of money still played a central role in his explanation of the cycle.

His focus on export variations inevitably led Prebisch to develop the other side of the coin, the role of imports and its relationship to exports. More precisely, changes in exports resulted in expenditure variations some of which then leaked to imports. The extent of the leakage and hence the domestic impact of an export change depended on the size of the propensity to import. By construct Prebisch arrived in the early 1930's at 'the coefficient of expansion' or in more known terms, at the foreign trade multiplier.

His analysis of the foreign trade multiplier was a static one, an explanation of a change from one position of equilibrium to another, for a given circulation velocity of money and a constant propensity to import. The generation of cycles required changes in either one or both of these variables. It was on this basis that he distinguished his analysis from that of Keynes multiplier approach emphasizing the latter's limitations, notwithstanding his later embracement of Keynes's General Theory of Employment, Interest and Money (1936) (GT, thereafter). ${ }^{14}$ It is clear that the severity of the balance of payments problems in the 1930s and his experience as director of the central bank led to this early preoccupation with the open economy dimension of the multiplier, and to develop a view of the balance of payments as a limit to the level of activity in peripheral countries.

The development of his views on the cycle did not alter his belief that these were inevitable, with recurrent and symmetric upward and downward phases, and ultimately 'natural.' Nonetheless, he became convinced over time that policy could extract the 'boom' and 'bust' character of the cycle through orderly and centralized interventions, avoiding thus the excesses of the upward phase of the cycle and hence the painful adjustment of contraction and liquidation, of which he had become aware partly through experience and partly through his reading of Gesell $(1891 ; 1909)$ and Keynes (1923).

Such was one of the tasks assigned to the Central Bank, whose creation in 1935, on the basis of Prebisch's ideas, followed the abandonment, in 1929, of the fetters imposed on policy by the Gold Standard. Fundamental to this task was the use of open market, foreign market exchange operations and controls, moral suasion and, most important for its current day relevance, reserve accumulation for precautionary purposes. ${ }^{15}$

In practice the Central Bank not only acted to extract the 'boom' and 'bust' character of the cycle, but in fact, aware of the detrimental effects of the 1937 contraction, came eventually to mitigate the amplitude and intensity of its regular

\footnotetext{
${ }^{14}$ See, Prebisch's (1947) and (Vol. IV. pp. 244-361).

${ }^{15}$ The introduction of foreign exchange controls (which lasted until the 1940's) for the first time in 1931 was prior to the creation of the Central Bank. See Table 8 in the Annex for further details. The ultimate goal of this measure is unclear. In Pollock et al. (2002, p. 544), it seems the ultimate goal at this time of exchange controls and other measures was to reduce the fiscal deficit, a very orthodox measure and in this sense a far cry from a counter cyclical stance. In Mallorquín (2006), Prebisch seems to emphasize the goal of softening the external constraint and terms the 1931 imposition of exchange controls, a "heterodox move.'
} 
fluctuations and thereafter, following the start of WWII, to implicitly target domestic activity, through counter-cyclical policy. ${ }^{16}$ The consideration of two targets, the stability of money and that of output, seems to have led Prebisch to consider the possibility of a short-run inflation-output trade off, one of the central pillars of modern macroeconomics, however crudely stated at the time.

Prebisch's thrust for policy autonomy, his counter cyclical stance and experiments with different sets of instruments including foreign exchange and import controls, helped to shape Robert Triffin's views on central banking who led in the 1940's a series of US Federal Reserve financial missions to Latin America. ${ }^{17}$ However, it should be noted, that counter-cyclical actions remained for the most part confined mainly to monetary policy since Prebisch, except for a few occasions, remained committed to fiscal orthodoxy.

Prebisch not only focused on policy design to dampen cycle fluctuations and thus output volatility, but also devised an approach to take advantage of expansions to achieve sustained growth over time without exacerbating the conditions of the upward phase of the cycle. Besides considering the use of capital controls, he recommended during and after WWII insulating the domestic economy from international disruptions. This required a process of substitution of domestic industry and production for foreign goods. This call for national policy space and autonomy is reminiscent of Keynes's longstanding concern with creating the conditions under which countries could freely pursue domestic objectives, including full employment, and predates that of modern day Keynesians such as James Tobin. ${ }^{18}$

Towards the middle of the 1940's he became convinced that, cycles were not a national and country phenomenon. Rather cycles were global in nature and the observed country cycles, such as those of Argentina, were in fact part of the realization of a singleglobal cycle process. Cycles were initiated in developed countries, due to their economic importance, and more specifically in the economically predominant developed country at the time (first the United States and then Great Britain) or as Prebisch called it in the cyclical center. Countries such as those of Latin America who are subject to the effects of the economic impulses generated by the cyclical center were considered as the periphery.

Following this line of thought, Prebisch argued for the need to articulate a universal and general cycle theory, encompassing the analysis of the different phases of economic activity in the periphery and in the center as well as their interaction. Far from being fully developed, the general cycle theory or as he called it, the 'theory of economic dynamics,' remained at the level of class lecture notes. Prebisch did not incorporate the accelerator dynamics, which was typical of other endogenous approaches to business

\footnotetext{
${ }^{16}$ Prebisch dates the beginnings of counter-cyclical policy to 1933 probably influenced by Keynes' Means to Prosperity (1933) and also by the failure of the World Economic Conference. See, RP, Vol. I.p.146; Vol. IV, p.126 and 139). In the 1930's counter-cyclical policy was recommended by a majority of economists at the time on both sides of the Atlantic including J.H. Williams.

${ }^{17}$ According to Helleiner (2009, p. 18): “Triffin frequently cited his debt to Prebisch's 'pioneering work' in his publications... Triffin did not just draw on Prebisch's ideas in his own work but also invited him on various Federal Reserve Board financial missions, including the all-important Paraguayan mission [1945]."

${ }^{18}$ Well known examples include Keynes defense of 'National Self-Sufficiency,' his proposal for 'controls on capital movement' as a way to render inoperative the Uncovered Interest Rate Parity theorem (which he put forward in 1923) allowing countries to regain control of interest rate policy, his opposition to free trade, and in general his Currency Union Proposal. For his part James Tobin (1974, p. 92) has justified his Tobin Tax by "...the need to protect national autonomy in stabilization policy by deliberately contrived obstacles to international flow of funds."
} 
fluctuations of the time e.g., Kalecki (1933), Clark (1935b), Harrod (1936), and Samuelson (1939).

Nevertheless, this incipient theory of economic dynamics besides being built around the better known concepts of center and periphery, also incorporated those of capital accumulation and technological progress, associated with Prebisch's name and which were to play such a central role in the development of his thinking on Latin American Industrialization during his ECLAC years (1948(9)-1963). ${ }^{19}$

\section{The business cycle and its initiating factors}

Up until the time of the Great Depression, the initiating factor of the Prebisch cycle is international borrowing (i.e., a capital transfer) which leads to an increase in metallic (specie) reserves. This follows closely the views advanced by Taussig (1917, 1927) whose analysis also emphasized the effects of international borrowing (capital transfer) on the external and liquidity positions and on prices. ${ }^{20}$

At the beginning of the second cycle (1867-1876), studied by Prebisch metallic (specie) reserves tripled between 1867 and 1871(3.5 and 10.5 million pesos) and reached its maximum in 1872 (15.4 million pesos). Prebisch attributes the increase in metallic reserve mainly to public and to a lesser extent to private loans. ${ }^{21}$ As he put it (RP, Vol. I, p. 115):

"The flow of public loans began with vigor in 1868, reaches its maximum between 1871 and 1873 and became extinguished in 1874 until the next decade. Besides these and other public loans, the country began to borrow significant volumes of foreign capital for the development of productive forces, attracted by the relative pacification of the country."

\footnotetext{
${ }^{19}$ In late 1948, Raúl Prebisch accepted a short-term position at the newly formed Economic Commission for Latin America (ECLA, later renamed as ECLAC to officially include the Caribbean in its denomination), who's Executive Secretary was Gustavo Martinez-Cabañas. Prebisch was only appointed Executive Secretary in 1950 after the Montevideo Conference (Dosman, 2008, p. 265). It is important to note that while Prebisch was developing Keynesian ideas adapted to the particular circumstances of peripheral countries, his participation in the conservative governments of the 1930s, his dismissal from the central bank by the government of the 1943 military coup, and his troubled relation with the Peronist government (1946-55), in Argentina he would not be seen as particularly Keynesian, and his policy advise would be seen as contradictory to his international policy positions. See Sikkink (1988).

${ }^{20}$ Taussig emphasized the effects on both the lender and borrowing country. See also appendix C ("The Harvard Neoclassical School") in Bordo (1984).

${ }^{21}$ Available evidence of foreign inflows to Argentina dates back to the year 1865, which coincides with the start of the Triple Alliance War. According to Ferns (1950 p. 27) British investment in joint stock enterprises and public funds reached 5.4 million pounds during that year, twice that registered for the first year available, 1857. Stone (1968 and 1977) provides a lower estimate of the order of 2.7 million pounds of which $80 \%$ corresponded to government debt. The seminal study by Peters (1934, p.23) provides a similar estimate of government external debt flows (2.5 million pounds). However, effectively Argentina received a smaller amount. The 2.5 million pound loan was first reduced first to 1.25 million pounds due to 'strained conditions of the market after a period of intense speculation' and then only half a million pounds was subscribed due to the increase in the rate of interest by the Bank of England making Argentine Bonds 'unattractive' (Ibid).21 The rest of the loan was issued in 1868. Peters, Ibid, also attributes the failure to subscribe the full amount of the loan responds to that fact this was the first time that the Argentine Republic appeared in the London money market. In the past as in 1824, the Buenos Aires province issued loans. As put by Peters, Ibid, "Besides the unfavorable conditions in the money market, the lack of knowledge of and confidence in the Argentine Republic, as distinct from Buenos Aires led to the failure of the attempt."
} 
And (ibid. p. 119):

"The external loans undertaken by the country between 1867 and 1873 must have been considerable. They not only allowed the increase of internal circulation of money, but also made possible the extraordinary swelling of imports, stimulated by the increase in prices following the inflation and by the reigning atmosphere of artificial prosperity that incited imports to over evaluate their needs....Without loans the country would not have been able to pay for the considerable import sum; as well loans explain the paradox of an unfavorable trade balance and the increase in the stock of metallic currency in the country."

A similar depiction is provided as the basis for the third cycle (1881-1885) analyzed by Prebisch (ibid. p. 138):

"...the fundamental fact about imports of metallic and foreign loans is to have acted as objective causes of a new ascendant period [1881-1884], analogous to the previous crisis. Real estate property, whose values became depressed towards the end of that one, began once again to inflate its prices. Businesses became more active in the heat of greater credit facility and in turn reacted on it, in the sense of greater expansion; this credit abundance was based was founded upon in the increase in real capital of the official banks...constituted by gold loans, and in the growth of deposits due to a greater amount of monetary circulation." 22

History repeated itself in 1887 as Argentina received inflows of foreign financial flows initiating Prebisch's fourth economic cycle. For this particular cycle, inflows are explained mainly by private sector operations (including railway construction, foreign exchange operation related to real estate properties (the issue of the so-called 'cédulas')) and to a lesser extent by governmental loans. Available data shows that between 1886 and 1888, total loans increased from 67 to 247 million gold pesos. Thereafter the demand for loans declined. The share of foreign loans to the private sector, which represented $38 \%$ of the total in 1886, increased its share significantly and accounted for roughly $70 \%$ of total loans on average from 1887 to 1891 (See Figure 1 below). Of the total private sector loans, $41 \%$ originated in real estate property deals and $48 \%$ in railroad infrastructure on average (Di Tella \& Zymelman, 1973, p.35, Table 2).

Figure 1: Argentina: Public and private external loans 1886-1891 (Million Gold Pesos).

\footnotetext{
${ }^{22}$ There is no available evidence quantifying the value of external financial flows for this cycle. Ferns (1950), presents evidence for the years, 1957, 1865, 1875, 1885, 1890, 1900. For his part Stone (1977) shows data for the years 1865, 1875, 1885, 1905 and 1913 respectively. It should be noted that starting in the last quarter of the nineteenth century the Argentinean government also managed to obtain funds from the issue of internal bonds and that the government also obtained resources from the selling of land.
} 


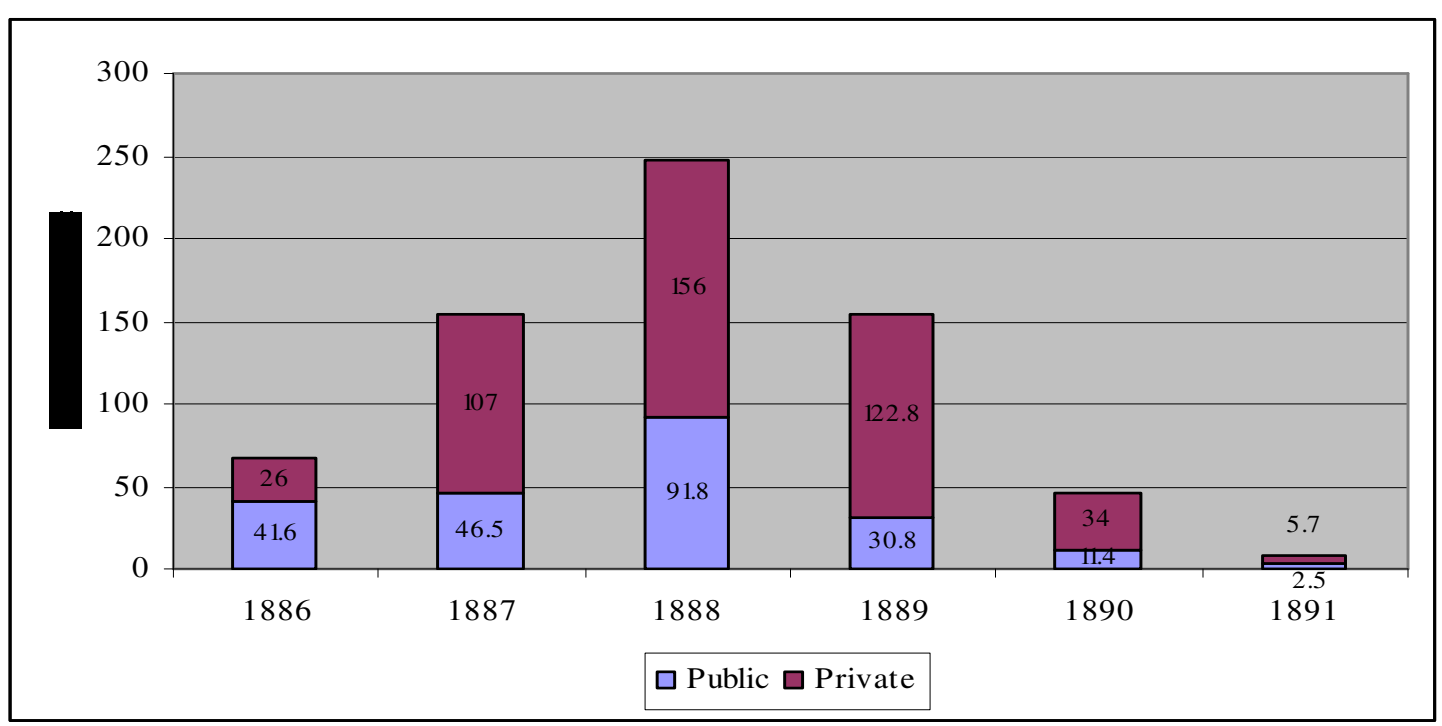

Source: Own computations on the basis of RP, Vol. I, p. 143

The same phenomenon occurs following the Conversion Law of 1899 and in 1927 during the brief restoration of convertibility. In the former case the stock of metallic currency more than doubles between 1905 and 1912 increasing from 139 to 291 million pesos. In the latter case, it increased by $38 \%$ between the beginning of 1927 and the first half of 1928. This evidence prompted Prebisch to repeat his adagio in the case of the 1899 convertibility experiment (Ibid, p.165): “... at the heat of foreign gold, a new ascending period of a crisis was incubated, analogous in many aspects to those that preceded the collapses of 1875,1885 and 1890."

The facility with which Argentina received financial flows in the initiating years of the above cycles reflected no doubt the conditions prevailing in the international monetary markets and in particular those of the London market. ${ }^{23}$ Starting in the second half of the $19^{\text {th }}$ Century, Great Britain became a leading financial center and the main investor in Latin America accounting for roughly 44\% of world total on average between 1875 and 1924. Between that time and 1913, British foreign investment in Argentina increased from 23 to 480 million pounds allowing the country to raise its Latin American British share from $13 \%$ to $41 \%{ }^{24}$

\footnotetext{
${ }^{23}$ Britain experienced an economic boom from 1858 to 1873 . During this period important changes took place in the London money market. Morgan (1965) emphasizes two major changes. The first is the "growth of the international acceptance business." This was fundamental in transforming London into an international banking center. As he puts it (Ibid, p. 167): "In the 1850's [international acceptance business] the system was extended so that bills drawn by a foreign house on a firm in a third country were accepted by a London firm and so rendered available for discount in the London market. .... large part of the trade in the world came to be financed, and London became a sort of clearing house for international payments." The second change is that as a result of political and civil disturbances in the nineteenth century (including the American Civil War and the Franco-Prussian War), of which Britain was free money flowed to the London financial market. In 1873, Europe and the United States were subject to severe financial crises. The consequences lasted until 1880 when financial and real activity recovered maintaining the pace of recovery until 1884. The next recovery phase stated in 1887 lasting until the Baring crisis (1890-1891).

${ }^{24}$ As table 2 below shows, Argentina's share of British investments in Latin America grew over time. The division of British inflows into, direct and portfolio investment, shows that while the latter was an important source of finance, over time, it diminished in importance in relation to the former.
} 
The influence of external conditions was recognized by Prebisch early on in his analyses of the second cycle and played a significant and growing role in his explanations of the Argentina cycle in general. As he argued: "The ascending period of the Argentine Crisis...develops in parallel to the ascending period of a general European crisis that explodes in Vienna in 1873" (RP, Vol. I., p. 126 note 66). ${ }^{25}$ In a similar vein he would explain in 1929 as he recapitulated his views on the Argentina cycle (RP Vol. I, p.553): "In their periods of abundance... European countries... lent us freely their capitals...in so far as those conditions were maintained we could easily cover the financial services due on those capitals..."

Prebisch came to the realization that besides financial flows, changes in the conditions that affected export performance could also act as initiating factors of the economic cycle. But he introduced export performance into the cycle as he became aware that agricultural prices had registered a declining trend since the middle of the 1920's and that the Great Depression sharply aggravated this contraction (See Figure 2 below).

Table 2

Indicators of British investment in Argentina and the World (1865-1913)

\begin{tabular}{|c|c|c|c|c|c|c|}
\hline & 1865 & 1875 & 1885 & 1895 & 1905 & 1913 \\
\hline Argentina/Latin America total & 3.34 & 12.94 & 18.36 & 34.55 & 36.83 & 40.66 \\
\hline Argentina direct/Latin America total & 2.92 & 14.70 & 24.06 & 41.77 & 45.74 & 47.35 \\
\hline Argentina portfolio/ Latin America total & 3.45 & 12.39 & 15.68 & 29.32 & 28.70 & 34.98 \\
\hline Argentina portfolio/Argentina FDI & 4.40 & 2.70 & 1.38 & 0.97 & 0.69 & 0.86 \\
\hline Argentina government/Argentina total & 81.5 & 73.0 & 58.0 & 47.5 & 39.8 & 38.5 \\
\hline World & & & & & & 1.09 \\
\hline World portfolio/World FDI & 3.73 & 3.21 & 2.12 & 1.38 & 1.16 \\
\hline Source: On the basis of Stone (1977)
\end{tabular}

${ }^{25}$ The 1873 crisis is considered the first 'authentic global financial crisis' (Marichal, 2009). It effects were felt in several Latin America countries including Argentina. Several Argentine authors including Francisco Balbín, Rufino Varela, O. Garridós, J. Terry, and Juan Bautista Alberdi, among others, analyzed its effects on Argentina. 
Figure 2: Argentina. Agricultural (gold) price index actual and Hodrick-Prescott trend; 1910-1914=100), 1900-1933.

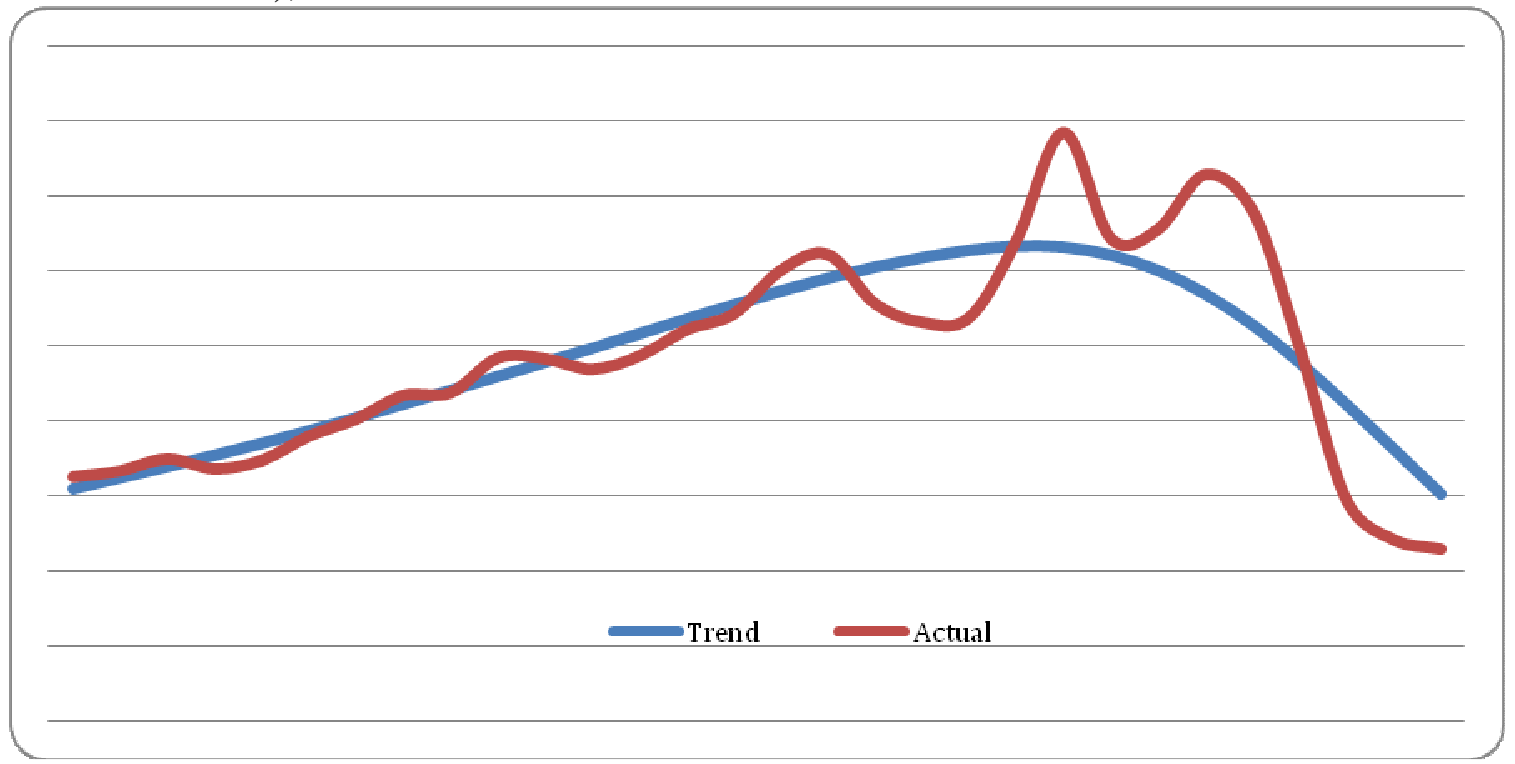

Source: Computations of the authors on the basis of Prebisch (RP, Vol. II, pp.132-134 and p. 141).

Available data presented by Prebisch for 1900-1933 shows that the trend of agricultural prices increased between 1900 and 1925 (5\% yearly average) and thereafter declined (-7\% on average between 1925 and 1933). The decline was steeper following the start of the Great Depression. In fact, Prebisch argued that the contraction was so sharp that the agricultural price index reached levels around 1933 that it had not witnessed since the nineteenth century. The comparison with the situation in industrialized countries whose manufacturing export prices had not decreased and in some case had actually risen led inevitably to terms-of-trade considerations (RP Vol. II, p. 188-191), most likely providing an antecedent to the Prebisch-Singer hypothesis more concerned with the cyclical downturns of the terms of trade than with the secular trend. ${ }^{26}$

Thus by the early 1930's the fluctuations in the economic cycle were seen as dependent on both the conditions in international monetary markets and export performance. He explains it in the following way in an article titled The Economic State (1930) (RP, Vol. I., p. 634): "Recently, we referred to the predominating influence on our monetary cycle of the events in the international money market in New York, as before

\footnotetext{
${ }^{26}$ Prebisch (RP Vol. II, p. 191) quotes from the League of Nations (1932-1933) World Economic Survey, making the point that in those years, the purchasing power (terms-of-trade) of agricultural countries declined while that of industrialized countries increased due to a relative greater fall in their import, than export prices. Data presented for five industrialized countries (Germany, the United States, France, Great Britain and Switzerland) shows that all managed to improved their terms-of-trade between 1929 and 1933 (45\%, 33\%, 16\% 20\% and 12\% respectively). By contrast, data for five agricultural countries (Argentina, Australia, Canada, Denmark and New Zealand) for 1929-1931 show a worsening of the terms-of-trade ($32 \%,-35 \%,-10 \%,-16 \%$, and $-38 \%$ respectively). The Prebisch-Singer hypothesis refers to a secular decline in developing countries terms-of-trade with industrialized countries. The hypothesis was put forward by Prebisch and Singer in 1950 independently. See RP, Vol. IV, Singer (1950 and 1987), Palma (1987).
} 
the war it happened with that of London. It is to be pointed now the consequences that for Argentina the variations in foreign purchasing power."27

A similar but more developed and sophisticated statement was provided eight years later in "The Economic Cycle and Monetary Policy" (1938) stating in a straightforward manner (RP Vol. II. P. 647-648): “... in the development of our wave motion prevail, on the one side, the variations of the physical volume of soil production, its prices and the degree of absorption of the products in the international market, and on the other side, the more of less affluence of foreign capital... The intensity of our cycles not only depends on the isolated force of each of these factors, but also on the form and opportunity with which they are juxtaposed joining in their action o neutralizing it between them in a variable degree., 28

\section{The change from boom (expansion) to bust (contractionary) conditions}

For Prebisch, the bust (downward phase) was a 'natural' and unavoidable sequence of the boom (expansionary phase). And in this sense the point of inflection from boom (expansion) to bust (contraction) was bound to occur. Moreover, the depth of the latter maintained a direct relationship with the intensity of the former. The greater the excesses of the boom (expansion) the more drastic would be the bust (contraction). At the same time, the bust (contraction) was not only unavoidable, but in fact necessary to prepare the stage for the next upward phase.

Coherently with this view, until Prebisch became convinced that a central monetary authority possessed the instrumental to attenuate the cycle phases (see section below on Money, the Cycle and Economic Policy), he thought that attempts to avoid the contractionary phase of the cycle (and more specifically a bust) could only have temporary effects and were in fact ultimately useless to a necessary process required to restore external equilibrium; a sine qua non condition for internal equilibrium. Moreover, by postponing what is viewed as a natural process, these measures are ultimately seen as artifices, which tend to aggravate the required correcting forces. Two illustrative examples are provided by the reactions to the busts in the 1867-1875 and 1881-1885 cycles.

In the 1867-1875 cycle, the government tried to avoid the bust phase by resorting to intervention in the foreign exchange market, maintaining the stability of the rate of discount or prime rate, the partial financial rescue of speculators, and the increase in the

\footnotetext{
${ }^{27}$ Prebisch similarly argues (ibid. p. 201) : "It is a well known fact that that the movements of our external trade constitute the decisive factor in the great changes of the Argentinean economic situation. We are linked in a very straight manner with the international economy and exposed to all of its changes. When the world market increases its absorption of our products...the acquisitive power of the population increases immediately; first in rural production....propagating throughout the entire field of our domestic economy translating into a more active demand for merchandises, both foreign and nationally made."

${ }^{28}$ Note that Prebisch acknowledges that the impulse provided by foreign capital can refer to both short and long run capital flows. He was clearly aware that short run capital is quick silver capital and leads to greater instability and can provoke changes in economic activity that are greater than those brought about by long term movements. (See, RP Vol. II, 307-313; Vol. III., p. 232; Vol. III, pp. 325 and 328-329. "From the point of view of the balance of payments, the inflow of short run capital flows in the same way as long run capital, stimulates imports, as a consequence the gold or foreign exchange that originally had entered under this concept flow out again due to the payment of imports. But if after that short term capital flows out unexpectedly it will be necessary to dispose of an additional quantity of foreign exchange to pay for it; whereas long run capital is paid for slowly"(RP Vol. III, p. 329).
} 
paper money supply to offset the decline in specie availability. Yet this only aggravated the situation as illustrated by the fact that the number of bad loans increased $\$ 343$ thousand to $\$ 4.3$ million between 1873 and 1876. Prebisch describes the process in the following way (RP. Vol. I, p. 122):

"The Office of changes witnessed the rapid diminution of its metallic reserves, since the peso holders solicited their conversion into gold...the office was able to face the conversion needs thanks to the efforts of its board of directors and to the cooperation of banks in particular which facilitated large sums [of gold]...but there came a moment in time when missing ...the obligations of the country had to be met in gold. In this way all measures had an ephemeral effect...in the face of the reduction in metallic reserves, non-conversion was an inevitable corollary. The government decreed it on the 16 of May 1876."

During the 1881-1885 cycle, faced with similar factors to those that ended the convertibility experiment of 1867, the Argentinean government tried to avoid the bust by suspending specie payments and maintaining a false sense of prosperity mediated by the issue of paper money and lasting until 1890. For him:

"... if the payments in metallic had not been suspended in 1885 ... a great part of the gold would have left the country to restore the equilibrium in the balance of payments, the quantity of money... (would have) suffered a brisk contraction and determined the liquidation of business and of the speculative activities and the decline in prices and real estate values...However,...the government declared the inconvertibility. With which the deflation of the currency which was its logical and sane consequence did not occur....the causes of the disequilibrium would continue acting with increased intensity preparing a stronger outcome than the one avoided with palliatives" (RP Vol. I, p. 141).

The turning point and triggering factor of the bust (contraction) for Prebisch is the same for all cycles considered, namely an unsustainable external position and more precisely an unsustainable current account deficit. This position is brought about by a combination of rising imports and/or higher service debt obligations and/or lower financial flows. The weight attributed to each of these factors depends on the specific cycle under consideration. 


\begin{tabular}{|c|c|c|c|c|c|c|c|}
\hline \multicolumn{8}{|c|}{$\begin{array}{c}\text { Table } 3 \\
\text { External indicators for selected years of the Prebisch cycles } \\
\text { (Year of the start of the cycle, two years after the cycle and peak of the cycle). (See notes for explanation and corresponding monetary units) }\end{array}$} \\
\hline Cycle phases & $\begin{array}{l}\text { Imports } \\
(1)\end{array}$ & $\begin{array}{l}\text { Exports } \\
(2)\end{array}$ & $\begin{array}{l}\text { Trade balance } \\
\text { (3) }\end{array}$ & $\begin{array}{c}\text { Debt Service } \\
\text { (4) }\end{array}$ & $\begin{array}{l}\text { Current account } \\
\text { (5) }\end{array}$ & $\begin{array}{l}\text { Capital account } \\
(6)\end{array}$ & $\begin{array}{l}\text { Balance of payments } \\
\text { (7) }\end{array}$ \\
\hline$\frac{\text { Start of Cycle }}{1867(\text { Cycle II })}$ & $\begin{array}{c}30.2 \\
(38.9)\end{array}$ & $\begin{array}{c}26.1 \\
(33.3)\end{array}$ & $\begin{array}{l}-4.2 \\
(-5.6)\end{array}$ & $\begin{array}{l}\cdots \\
\cdots\end{array}$ & $\begin{array}{l}\cdots \\
\cdots\end{array}$ & $\begin{array}{l}\cdots \\
\cdots\end{array}$ & $\begin{array}{l}3.5 \\
\ldots\end{array}$ \\
\hline 1881 (Cycle III) & $\begin{array}{c}55.7 \\
(51.5)\end{array}$ & $\begin{array}{c}57.9 \\
(58.1)\end{array}$ & $\begin{array}{c}2.1 \\
(5.6)\end{array}$ & $\begin{array}{c}-11.9 \\
\ldots\end{array}$ & $\begin{array}{l}-9.8 \\
(5.6)\end{array}$ & $\begin{array}{l}14.1 \\
(2.1)\end{array}$ & $\begin{array}{c}4.3 \\
(4.5)\end{array}$ \\
\hline 1886 (Cycle IV) & $\begin{array}{c}95.4 \\
(88.1)\end{array}$ & $\begin{array}{c}69.8 \\
(70.1)\end{array}$ & $\begin{array}{c}-25.6 \\
(-18.0)\end{array}$ & $\begin{array}{c}-26.7 \\
\ldots\end{array}$ & $\begin{array}{c}-52.3 \\
(-18.0)\end{array}$ & $\begin{array}{c}67.5 \\
(40.9)\end{array}$ & $\begin{array}{c}15.2 \\
(15.2)\end{array}$ \\
\hline 1903 (Cycle V) & $\begin{array}{c}\ldots \\
(121.5)\end{array}$ & $\begin{array}{c}213.2 \\
(222.4)\end{array}$ & $\begin{array}{c}\ldots \\
(99.1)\end{array}$ & $\begin{array}{l}\cdots \\
\cdots\end{array}$ & $\begin{array}{c}\ldots \\
(25.2)\end{array}$ & $\begin{array}{c}\ldots \\
(120.4)\end{array}$ & $\begin{array}{c}\ldots \\
(25.0)\end{array}$ \\
\hline 1927 (Cycle VI) & $\begin{array}{c}1,857.3 \\
(1,947.9)\end{array}$ & $\begin{array}{c}2,395.8 \\
(2,294.7)\end{array}$ & $\begin{array}{c}538.5 \\
(346.8)\end{array}$ & $\begin{array}{c}-162.0 \\
\ldots\end{array}$ & $\begin{array}{l}-12.0 \\
(192.4)\end{array}$ & $\begin{array}{c}289.8 \\
(259.9)\end{array}$ & $\begin{array}{c}277.8 \\
(324.1)\end{array}$ \\
\hline 1935 (Cycle VII) & $\begin{array}{l}1,175.0 \\
(937.6) \\
\end{array}$ & $\begin{array}{c}1,726.0 \\
(1505.8) \\
\end{array}$ & $\begin{array}{c}551.0 \\
(568.2) \\
\end{array}$ & $\begin{array}{c}194.0 \\
\ldots \\
\end{array}$ & $\begin{array}{l}-41.0 \\
(16.5) \\
\end{array}$ & $\begin{array}{l}117.0 \\
(61.5) \\
\end{array}$ & $\begin{array}{c}124.0 \\
(109.2)\end{array}$ \\
\hline$\frac{\text { Two years after Start }}{1869(\text { Cycle II })}$ & $\begin{array}{c}41.2 \\
(39.75)\end{array}$ & $\begin{array}{c}32.4 \\
(31.31)\end{array}$ & $\begin{array}{l}-8.7 \\
(-8.4)\end{array}$ & $\begin{array}{l}\cdots \\
\cdots\end{array}$ & $\begin{array}{l}\cdots \\
\cdots\end{array}$ & $\begin{array}{l}\cdots \\
\cdots\end{array}$ & $\begin{array}{l}3.9 \\
\ldots\end{array}$ \\
\hline 1883 (Cycle III) & $\begin{array}{c}80.4 \\
(80.7)\end{array}$ & $\begin{array}{c}60.2 \\
(60.4)\end{array}$ & $\begin{array}{l}-20.2 \\
(-20.3)\end{array}$ & $\begin{array}{c}-19.5 \\
\ldots\end{array}$ & $\begin{array}{c}-39.7 \\
(-20.3)\end{array}$ & $\begin{array}{c}47.4 \\
(28.0)\end{array}$ & $\begin{array}{c}7.7 \\
(7.7)\end{array}$ \\
\hline 1888 (Cycle IV) & $\begin{array}{c}128.4 \\
(118.6)\end{array}$ & $\begin{array}{c}100.1 \\
(100.4)\end{array}$ & $\begin{array}{c}-28.3 \\
(-18.2)\end{array}$ & $\begin{array}{c}-49.5 \\
\ldots\end{array}$ & $\begin{array}{c}-77.8 \\
(-18.2)\end{array}$ & $\begin{array}{c}247.8 \\
(199.0)\end{array}$ & $\begin{array}{c}170.0 \\
(170.6)\end{array}$ \\
\hline 1905 (Cycle V) & $\begin{array}{c}205.1 \\
(190.0)\end{array}$ & $\begin{array}{c}322.8 \\
(324.8)\end{array}$ & $\begin{array}{c}117.7 \\
(134.8)\end{array}$ & $\begin{array}{l}\ldots \\
\cdots\end{array}$ & $\begin{array}{c}\ldots \\
(.57 .2)\end{array}$ & $\begin{array}{c}\ldots \\
(120.6)\end{array}$ & $\begin{array}{c}\ldots \\
(31.9)\end{array}$ \\
\hline 1937(Cycle VII) & $\begin{array}{c}1,460.0 \\
(1, .357 .4)\end{array}$ & $\begin{array}{c}2,329.0 \\
(2,351.9)\end{array}$ & $\begin{array}{c}869.0 \\
(994.5) \\
\end{array}$ & $\begin{array}{c}-151.0 \\
\ldots\end{array}$ & $\begin{array}{c}718.0 \\
(397.8)\end{array}$ & $\begin{array}{c}-795.0 \\
(-444.6) \\
\end{array}$ & $\begin{array}{c}-77.0 \\
(-88.1)\end{array}$ \\
\hline
\end{tabular}


Table 3(Continued)

External indicators for selected years of the Prebisch cycles

(Year of the start of the cycle, two years after the cycle and peak of the cycle). (See notes for explanation and corresponding monetary units)

\begin{tabular}{|c|c|c|c|c|c|c|c|c|}
\hline \multicolumn{2}{|c|}{ Cycle phases } & $\begin{array}{l}\text { Imports } \\
\text { (1) }\end{array}$ & $\begin{array}{l}\text { Exports } \\
(2)\end{array}$ & $\begin{array}{c}\text { Trade balance } \\
\text { (3) }\end{array}$ & $\begin{array}{c}\text { Debt Service } \\
(4)\end{array}$ & $\begin{array}{c}\text { Current account } \\
\text { (5) }\end{array}$ & $\begin{array}{c}\text { Capital account } \\
\text { (6) }\end{array}$ & $\begin{array}{c}\text { Balance of payments } \\
\text { (7) }\end{array}$ \\
\hline \multicolumn{2}{|c|}{$\frac{\text { Peak of Cycle }}{1873-1874 \text { (Cycle II) }}$} & $\begin{array}{c}73.4 ; 57.8 \\
(70.85 ; 55.79)\end{array}$ & $\begin{array}{c}47.4 ; 44.5 \\
(45.73 ; 42.97)\end{array}$ & $\begin{array}{c}-26.0 ;-13.3 \\
(-25.1 \&-12.8)\end{array}$ & $\begin{array}{l}\ldots \\
\ldots\end{array}$ & $\begin{array}{l}\ldots \\
\ldots\end{array}$ & $\begin{array}{l}\cdots \\
\ldots\end{array}$ & $\begin{array}{c}10.2-6.2 \\
\ldots\end{array}$ \\
\hline 1884 & (Cycle III) & $\begin{array}{c}94.1 \\
(86.9)\end{array}$ & $\begin{array}{c}68.0 \\
(68.2)\end{array}$ & $\begin{array}{c}-26.1 \\
(-18.7)\end{array}$ & $\begin{array}{c}-27.6 \\
\ldots\end{array}$ & $\begin{array}{c}-53.7 \\
(-18.7)\end{array}$ & $\begin{array}{c}39.7 \\
(12.2)\end{array}$ & $\begin{array}{c}-14.0 \\
(-13.9)\end{array}$ \\
\hline 1890 & (Cycle IV) & $\begin{array}{c}142.2 \\
(131.4)\end{array}$ & $\begin{array}{c}10.8 \\
(97.3)\end{array}$ & $\begin{array}{l}-131.4 \\
(-34.1)\end{array}$ & $\begin{array}{c}-60.2 \\
\ldots\end{array}$ & $\begin{array}{l}-191.6 \\
(-34.1)\end{array}$ & $\begin{array}{c}45.3 \\
(-14.9)\end{array}$ & $\begin{array}{l}-146.3 \\
(-56.4)\end{array}$ \\
\hline 1913 & (Cycle V) & $\begin{array}{c}392.1 \\
(455.7)\end{array}$ & $\begin{array}{c}404.3 \\
(517.8)\end{array}$ & $\begin{array}{c}12.2 \\
(62.1)\end{array}$ & $\begin{array}{c}-177.3 \\
\ldots\end{array}$ & $\begin{array}{l}-165.1 \\
(-35.5)\end{array}$ & $\begin{array}{c}132.6 \\
(247.6)\end{array}$ & $\begin{array}{l}-32.5 \\
(3.5)\end{array}$ \\
\hline 1928 & (Cycle VI) & $\begin{array}{c}2,042.9 \\
(1,902.3) \\
\end{array}$ & $\begin{array}{r}2,275.9 \\
(2,397.4) \\
\end{array}$ & $\begin{array}{r}233.0 \\
(492.0)\end{array}$ & $\begin{array}{l}\ldots \\
\ldots\end{array}$ & $\begin{array}{l}-317.0 \\
(341.2)\end{array}$ & $\begin{array}{c}32.0 \\
(295.4)\end{array}$ & $\begin{array}{l}-349.0 \\
(314.2) \\
\end{array}$ \\
\hline
\end{tabular}

Notes: The figures were constructed on the basis of those provided by RP, Vols. I to III. The figures in parenthesis are on the basis of the data provided by Ferreres (2005, Tables 8.1.1 and 8.2) and are included only for comparative purposes. The data provided for cycles II to V are in million gold pesos or pesos fuertes. The data for cycle VI are in million of pesos. The result of the balance of payments (column 7) corresponds to the variation of reserves in the case of Ferreres including errors and omissions. In the case of the data from Prebisch (op.cit.), the variation of reserves corresponds to metallic reserves for Cycle II and to the difference between external assets and liabilities for cycles III to VII. In the case of the data obtained from Prebisch (op.cit) only the trade balance plus the stock of metallic reserves is available for cycle II. In the case of cycle IV, data availability includes exports and imports, debt services and capital inflows (i.e., loans). From cycle V onwards the data on the balance of payments is much more detailed in terms of assets and liabilities. As a result the current account result include remittances and also profit repatriation .In the case of Ferreres, detailed data on the current account balance is available from Cycle V onwards. Data on the capital account is not available on a disaggregated basis for any of the cycles considered as it is for Prebisch in the cases of cycles V and VI. The source data used by Prebisch for cycle VI (1927-1929) are from Tornquist (1930) and for cycle VII from national statistical sources (Estadística Nacional).

Source: On the basis of RP, Vols. I-III and Ferreres (2005). 
As with his analysis of the initiating factors of the cycle, Prebisch was aware and understood the importance of external conditions in influencing the change from boom (expansion) to bust (contraction), and in particular that of international financial markets. ${ }^{29}$ Eventually Prebisch gave paramount importance to external conditions and argued in 1944 that the Argentine cycle is a mirror of the international monetary cycle (RP, Vol. III, pp. 321-322). Nonetheless until that time he argued that the adequate management of internal conditions especially prudence in the conduct of economic policy during the boom (expansion), could substantially attenuate the impact on domestic activity of external 'shocks.' 30

At a general level in the first two cycles (1867-1873 and 1881-1883) the weight of the explanation of the inflection from boom (expansion) to bust (contraction) is placed on the rise in imports that is on a 'real side variable.' A minor role is attributed to rising debt services obligations coupled with a reduction in financial inflows (RP, Vol. I. pp. 120 and 142) that is, to 'financial variables.'

As shown in table 3 above (which provides data for exports, imports, the trade balance, debt service, current account, capital account and the overall balance-ofpayments result) at the start of the Prebisch cycles, two years after the beginning of each cycle and finally for the peak years of the respective cycles using his sources), imports tend to increase after the start of the cycle.

As a result of the rise in imports the trade imbalance expands between the start and peak of the cycle. The trade imbalance reached -4.2 million gold pesos at the beginning of the second cycle and widens by a fifth-fold to reach 26 million gold pesos at the peak. In the case of the third cycle an initial trade surplus worth 2 million gold pesos in 1881 turns into a deficit equivalent to -26 gold pesos in 1884.

In his explanation, Prebisch hardly mentions the behavior of exports as a contributing factor to the trade imbalance. While this is justified in the 1881-1885 cycle as the growing import (mainly consumer goods and raw materials) needs surpassed the expansion of exports; the growing external deficit in the cycle 1867-1875 can be attributed in part to poor export performance (see Figure 3 below).

Between the start of the Caisse in 1867 and during the next four years until 1871, the most notable fact explaining the deficit in the trade balance is not so much the increase in imports which were not above their trend during this time, but rather the significant drop in exports. Between 1867 and 1871 exports declined by $23 \%$ in value

\footnotetext{
${ }^{29}$ Curiously enough while Prebisch recognized the importance of external conditions in the initiation of the cycle he did not always attribute the same significance to their role in the bust. As an example, when analyzing the factors that led to the bust (contraction) in the 1867-1876 cycle he states (Vol. I, pp.199-120), "A greater part of the gold had been exported in payment of public debts, dividends of firms with foreign capital... etc.; in other words the liabilities of the loan balance grew. It also not unsafe to say, that the asset side of this balance declined due to the tension in the European monetary markets in 1873, consequent upon the continental panic begun in Vienna; tension that must have made difficult the recruitment of new loans in the financial market of Europe."

${ }^{30}$ In this regard he writes (RP, Vol. I., p. 554): “...if we had administered prudently the increase in metallic reserves, the export of gold provoked by high foreign interest rates, caused only a mild recess in the prosperity of our commerce. But if it were employed generously in the expansion of money and credit without forestalling speculative excesses, the outflows of gold precipitated the outcome of a more or less severe crisis."
} 
terms due to part a drop in export prices, competition for Argentinean exports from New Zealand and Australia and the end of the Civil War in the United States. ${ }^{31}$

Figure 3: Argentina. Real export and import indices and coverage ratio (1863-1879)

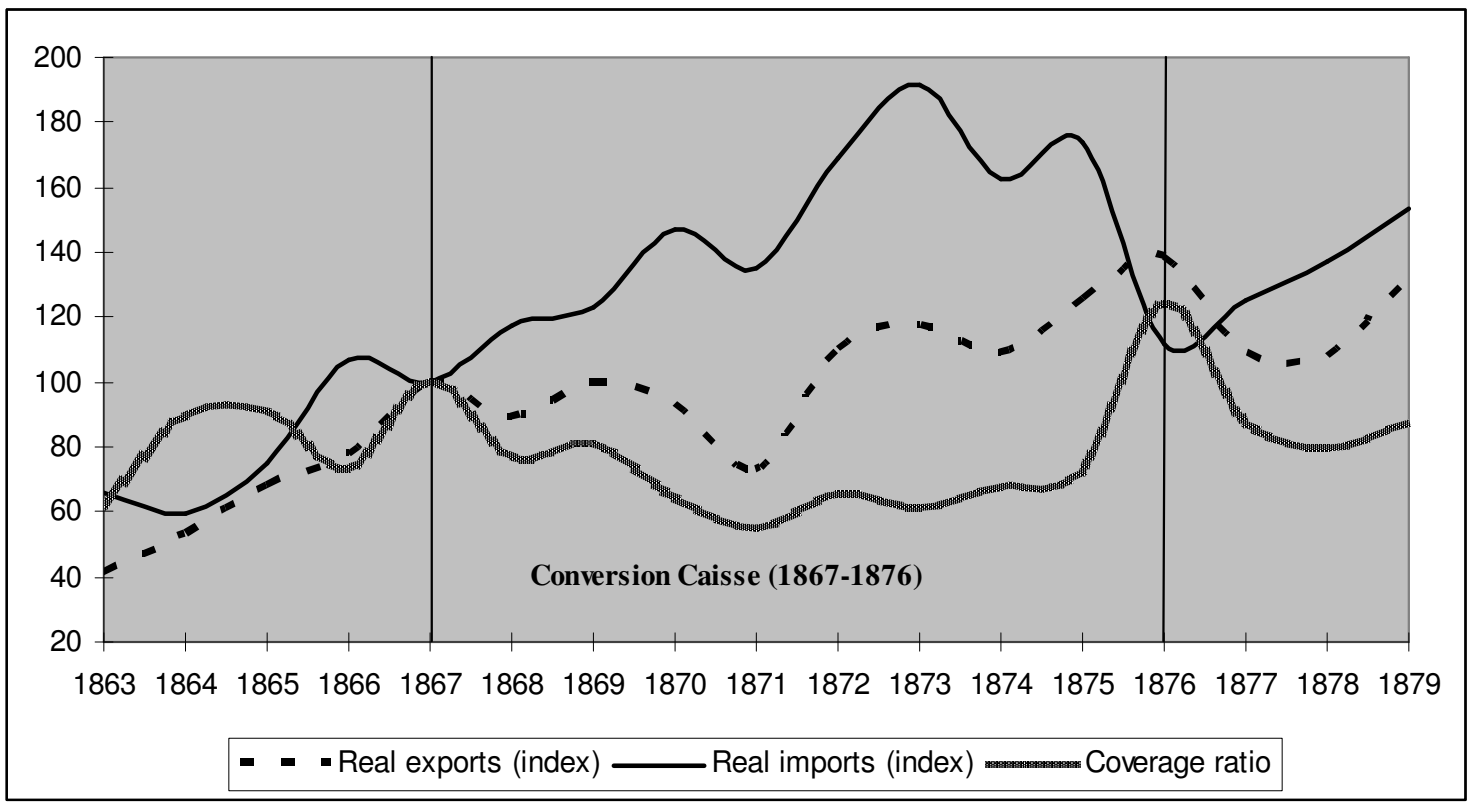

Source: On the basis of RP, Vol. I. and Ferreres (2005).

Contrarily to the first two cycles analyzed by Prebisch, financial factors become a paramount explanatory variable in the turning points of the next three cycles (1886-1890; 1903-1914, 1927-1933). More precisely the bust in the 1886-1890 cycle is attributed fundamentally to a violent contraction in external loans (RP, Vol. I, pp. 155-156). For its part the turning point in the 1903-1914 episode, is explained by a combination of lower inflows and higher debt service obligations. Finally terms-of-trade, external demand conditions, and in particular financial factors, explain the inflection point in the 19271933 (RP, Vol. I, pp. 584-586; Vol. II, p. 64 and pp. 158-200), and the 1939-1944 cycles. $^{32}$

\section{The transmission mechanism in the boom and the bust (expansionary and contractionary phases)}

In consonance with his understanding that the boom (expansion) and bust (contraction) are symmetric phases of the realization of same process, Prebisch argued

\footnotetext{
${ }^{31}$ Newland (1998, Table 2, p. 412) gives an estimate export drop of $-19 \%$ on average between 1861-1865 and 1866-1871. He also provides evidence for a rise in import prices ( $8 \%$ between the same periods). As a result the terms of trade declined by $17 \%$. Panettieri, 1980, p. 396, provides evidence along similar lines for wool exports showing a $-16 \%$ reduction between 1867/1868 and 1869/1870.

${ }^{32}$ In the 1927-1928 cycle, other items such as remittances of Argentina to the rest of the world and travel expenses also contributed to widen the external imbalance. The external accounts for the first three cycles (1867-1875; 1881-1890 and 1899-1913) are presented in terms of exports and new loans (on the credit side); imports and loan services (on the debit side). By the time Prebisch analyzed the 1927-1929 cycle he possessed a wider set of data at his disposal and was able to provide a more sophisticated presentation of the balance of payments.
} 
that the same forces pushing economic activity in the boom (expansion) would act in the opposite direction in the bust (contraction). His transmission mechanism followed the lines dictated by the monetary theories of the trade cycle and the quantity theory of money, placing changes in the flow of money and their effect on activity, prices and imports at the center stage of his explanation. ${ }^{33}$

The increase in financial flows or the rise of exports above import demand due to an increase in external demand, a rise in export prices or a combination of both translates into an excess supply of foreign exchange. Banks expand their lending base due to the acquisition of letters of credits from exporters, which leads to an increase in deposits and thus loans, and also as a result of the increase in the stock of metallic currency. The consequent increase in liquidity leads eventually to an increase in imports. (RP, Vol. II. p. 648; Vol. III, pp. 249-250; pp. 320-329).

In his analysis of the cycles prior to the Great Depression, the rise in imports responded to the increase in prices and the improvement in business conditions concomitant upon the expansion of liquidity. As he put it in the case the 1905-1914 cycle, which exemplifies his views on the transmission mechanism at this, stage (RP, Vol. I, p. 168):

"...through the foreign exchange market, are produced the inflows and outflows of metallic currency, that influence on the quantity of money and through this one on prices and business conditions; these two factors react in turn on the balance of payments. It is in this way that...the swelling of imports has found its direct and indirect stimulus through the level of prices and the times of boom brought about by the expansion of the circulating media."

Following the Great Depression rather than emphasizing price effects in the relationship between the increase in liquidity, prices and imports as in his earlier interpretation of the cycle, he centers on income effects, arguing that imports increase because: "a considerable part of the direct consumption in the country, or machinery or materials for its industries, comes from abroad" (RP, Vol. II p. 74) and (Ibid. p. 648) "the positive balance in the international accounts is manifest in a dilation of the means of payments...the general demand for goods and services increases; and imports, which in our country are very sensitive, will feel rapidly the pinch." 34

As a result of the rise in imports, the widening of the external imbalance led inevitably to the export of gold (specie), and a contraction in liquidity leading to deflation and liquidation. As argued above, Prebisch sees this bust (contraction) phase as a logical consequence of the 'exorbitant increase in money supply,' which accompanies the boom (expansion) phase of the business cycle.

More to the point he conceived this phase as symmetrical to the boom (expansionary) phase. The same factors that propped up the economy on its upward phase

\footnotetext{
${ }^{33}$ See, Hawtrey ([1919], 1950) and Taussig ([1911] 1915, 1917, 1927).

${ }^{34}$ Prebisch (RP, Vol. II, pp. 648-649) provides an example of an increase of 300 million pesos in income of which $80 \%$ and $20 \%$ respectively are spent on domestic and foreign goods. Simple computations show that after 30 periods the expenditure on domestic goods equals 1,199 millions and that on imported goods reaches 300 million (that is the amount of the increase in income). The multiplier in Prebisch's example is 3.99 .
} 
pull down the economy in the downward phase. As he put it with regard to the second boom-bust cycle (RP, Vol. I. p.120):

"And just as the abundance in capital brought about easy and cheap credit, so did its scarcity, as soon as they began to be removed from circulation, made credit more difficult to obtain and increased the rate of interest...And there began....a descending period characterized by credit restriction, liquidation and business depression...the trade malaise intensified ... real estate speculation, bereft of easy and abundant credit began its involution..."

A similar statement is found in his analysis of the 1927-1928 cycle (RP, Vol. I p. 583): "the decline in metallic stock engenders a series of perturbations which are characteristic of the descending phase of the monetary cycle initiated when gold flowed to our country. And those factors that promote this development are precisely the opposite of those that intervened in the preceding ascending phase. $" 35$

Initially at this stage he labeled the effects of the bust (contraction) as natural and healthy, and as a cleansing of the bad elements as did some of the prominent economists of the same as for example Schumpeter (e.g. RP, Vol. II, p. 601 and footnote 39 below), A similar account permeates his analysis of the bust (contraction) in the case of the 19051914 cycle. As he put it (RP, Vol. I, p.171): "With the beginning of the first outflows of metallic currency and consequently of the rarefaction of money [bills] in circulation, lack of confidence abounds and banks restrain their credit. The more imprudent is the previous policy the more intense will the restriction..." This monetary reaction is particularly harsh on speculators and those that has abused of the easiness of credit conditions. Furthermore while, it affected 'true and sane' businesses, these managed to weather the storm and remain in business. All in all, this was according to Prebisch the logical reverse, a natural and sane reaction to a previous false and artificial prosperity.

However, eventually he came to recognize the painful and protracted effects of adjustment and deflation on economic activity. ${ }^{36}$ This resulted to a great extent from the existence of imperfections and in particular contracts fixed in money terms, rigid and fixed costs such as wages and in general production costs. As well deflation swelled the debt burden (Vol. I., pp. 59-60 also p. 135). These arguments formed the basis on which to question the beneficial of 'liquidation' during the downward phase of the cycle. In this regard it is useful to quote Prebisch at length (RP, Vol. II, pp. 47-48):

"A well known economic theory, of orthodox lineage, teaches, in effect, that situations of this nature, in times of crisis, are solved through liquidation. The theory is perfectly exact judged on the hypothesis on which it is based. It assumes

\footnotetext{
${ }^{35}$ See also RP Vol. III, p.232.

36 The negative effects of deflation were also highlighted by Silvio Gesell (1862-1930), a German economist who resided in Argentina from 1886 to 1900. Referring to the specific period of the end of the 19th Century in Argentina, Gesell stated: "..The increase in the value of money is the common cause for all the country's economic troubles" (La Anemia Monetaria, 1898). Keynes in his Tract on Monetary Reform ([1923], 1971) also pointed out the negative effects of deflation. Finally it is to be noted that these were highlighted by the early Chicago School of economics in terms similar to those of Prebisch at this stage of his thinking (that is in terms of nominal price and wage rigidities) and became the basis to recommend reflationary policies (e.g. Simons ([1934], (1962), p. 55).
} 
the case of a state of production which due to credit facilities has exceeded the consumption capacity of the market or the fictitious valorization of real estate property...sooner or later the market cannot absorb these goods or values at the prevailing prices...sales are paralyzed...The same theory provides the recipe: restrict credit and force liquidation...With liquidation banks recover their funds...the situation is cleared, through losses and bankruptcies, but the evil disappears...The inept are evicted and only the most gifted survive by selection. The most superficial reflection suffices to persuade that that theory of liquidation corresponds to factual data that are very distinct from the reality of Argentina." 37

The relationship between liquidity and prices and economic expansion and imports in the boom (upward phase) and the bust (downward phase) was mediated, not only the capacity of the banking system to expand and retract its credit base, but also the behavior of the circulation velocity of money and the propensity to import. The circulation velocity of money was partly driven by expectations encapsulated in what Prebisch termed 'the subjective factors.'

In his own word these included in the case of the boom (expansionary phase): 'the appreciation of the opportunities offered by Argentina and of the probabilities of rapid enrichment...stimulated the governing class...to contract European money...It's something subjective the confidence which...permits and accelerates the development of an ascending phase; thanks to it [confidence] businesses expand on the basis of credit and financial fantasy takes its flight'. In the bust (downward phase) during which the contraction in credit produces the collapse of economic activity, 'the insecurity, depression and mistrust maintain businesses stagnant, until the remembrance of tragic epochs becomes blurred and reborn confidence opens the way for a new cycle (RP, Vol, I, p. 161-162). ${ }^{38}$

As Prebisch became more concerned with the balance of trade and more precisely exports as an initiating factor of the cycle, the analysis of the transmission mechanism focused in more detail on the linkage and pass through between exports and imports. $\mathrm{He}$ argued that exports and imports 'vary correlatively,' that is a persistent upwards/downward movement in either imports (exports) tends to be accompanied by a movement in the same direction of exports (imports). Credit conditions, the circulation velocity of money and the propensity to import determined the pass-through (RP, Vol. III. pp. 336-343).

\footnotetext{
${ }^{37}$ See also the "Scholastic Inflation and Argentinean Currency" (1934, RP, Vol. II, pp. 336-350 and Vol. III, p. 348. 'Liquidation' was one the phases of the cycle identified by Juglar (1860) and became associated with the Austrian Theory of the business cycle (see for example Schumpeter ([1939], 1989, Hayek 1933) and with passive policies adopted by the Federal Reserve and the Edgar Hoover administration that deepened the Great Depression (See White, 2010 for a contrary opinion). Eichengreen (1999, pp. 8, 12) defines it as: “... liquidationism, according to which business cycle downturns served the Darwinian function of weeding out the weak enterprises least well adapted to a dynamic economy." As can be seen Prebisch understood liquidation and its effect in a very modern sense.

${ }^{38}$ Prebisch's depiction bears resemblance to Kindleberger's ([1978], 2005) cycle of manias and panics which is triggered by 'pro-cyclical changes in the supply of credit' leading to a boom (expansion) and a process of euphoria, overtrading, and speculation (manias). Eventually, there follow a period of financial distress, revulsion, panic and crash. Both Prebisch and Kindleberger emphasize the recurring character of manias and panics.
} 
As with his earlier cycle views he still recognizes that the budget deficit contributes to the expansion of liquidity and the increase in imports in the economy. However, in contrast to his previews views, the public deficit plays a role towards the end of the phase of expansion. The intervention of the public authorities prolongs the duration of the boom (expansionary phase), mitigates the impact of the decline in capital flows which occurs near the peak of the expansive phase partly offsetting the consequent contraction in liquidity and delaying the adjustment of imports to the new existing conditions (RP, Vol. II, pp.74-76).

\section{The coefficient of expansion and the foreign trade multiplier}

Prebisch further developed his analysis of the pass-through between export receipts, domestic activity and imports by introducing a concept in (circa 1935) termed the 'coefficient of expansion' (RP, Vol. III, pp. 249-298; 301-310; 335-342; 349-370). ${ }^{39}$ It measured the intensity with which an increment in incomes, resulting from a given increase in exports or financial flows, produces an expansion of greater amplitude in domestic economic activity.

Beginning with a position of equilibrium, he explains the workings of a one-time increase in exports in the following way (RP, Vol. III, p. 250):

"If for example, the volume of Argentinean exports increase -either due to an increase in exports or to the rise in prices- the agricultural sector will receive incomes correlatively higher allowing it to increase its demand for goods and services produced by other sectors and also for imported goods. There will be a higher demand for industrial goods; more commerce activity and in transportation; greater utilization of professional services and greater imports. At the same time, these sectors, that will have received more incomes will increase their demands for goods and services produced within the same sector and of other sectors and in this way will the influence or the effect of the initial growth in income of the agricultural sector produced by the increase in its exports successively expand."

Eventually the system will return to equilibrium when the rise in domestic incomes brought about by the expansion in exports leaks out through a greater volume of imports and other payments through the rest of the world.

Tables 1, 2 and 3 below show an illustration of Prebisch's coefficient of expansion on the basis of the full treatment provided in 1944 (ibid, pp.257 and 264-265). The example considers the income (columns) and expenditure (rows) of three sectors (agriculture, industry and non-tradables). In the example below, as a case in point, the agricultural sector earns 1,260, 730, 280 and 340 monetary units from exports and the non-tradable, industrial and agricultural sectors respectively. It spends 340, 590 and 1,270 monetary units on domestic products and services of agriculture, industry and nontradables. It also spends 400 monetary units on imports. The agricultural sector is the most dependent on export earnings (49\% of the total) with a roughly average propensity to import.

\footnotetext{
${ }^{39}$ See also Fernández-López (1996).
} 
The initial situation is one of full equilibrium with expenditure equal to income and, as expected, exports equal imports. In the example given by Prebisch, this initial situation is disturbed by a shock in the form of a one-time exogenous increase in exports of the agricultural sector by 1,000 monetary units. The resulting increase in the income of that sector is spent in other sectors according to the initial given proportions. That is, in the case of agriculture for example, $13 \%, 23 \%, 49 \%$ and $15 \%$ of the increase in income is spent in agriculture, industry, non-tradable sector and in imports respectively. ${ }^{40}$

\begin{tabular}{|c|c|c|c|c|c|}
\hline \multicolumn{6}{|c|}{$\begin{array}{l}\text { Table } 5 \\
\begin{array}{l}\text { Starting full equilibrium situation for the example of coefficient of expansion } \\
\text { (Income }=\text { expenditure }=13,700 \text { and Exports }=\text { imports }=2,000)\end{array}\end{array}$} \\
\hline \multirow[t]{3}{*}{ Income } & \multicolumn{5}{|c|}{ Expenditure } \\
\hline & \multicolumn{3}{|c|}{ Domestic activities } & Imports & Total \\
\hline & Agriculture & Industry & Non-tradables & & \\
\hline Agriculture & 340 & 590 & 1,270 & 400 & 2,600 \\
\hline Industry & 280 & 610 & 1,410 & 600 & 2,900 \\
\hline Non-tradables & 720 & 1,520 & 2,960 & 1,000 & 6,200 \\
\hline Exports & 1,260 & 180 & 560 & & 2,000 \\
\hline Total & 2,600 & 2,900 & 6,200 & 2,000 & 13,700 \\
\hline
\end{tabular}

Source: RP Vol. III, p. 255.

Eventually, successive rounds of spending lead to a situation where the cumulative expenditure in imports equals exactly the initial increase in exports $(1,339$ monetary units) (See Table 6 below). This occurs in the specific example provided by Prebisch after roughly 60 periods. At this point this three-sector economy returns to new position of equilibrium, where total exports equal total imports (3,339 monetary units) and income equals expenditure (22,910 monetary units) (see Table 7 below). The ultimate impact on total and domestic expenditure is 6 and 5 times the initial increase in exports.

40

\begin{tabular}{|c|c|c|c|c|c|}
\hline \multirow[t]{3}{*}{ Income } & \multicolumn{5}{|c|}{$\begin{array}{c}\text { Table } 4 \\
\text { Domestic and import expenditure coefficients for each sector }\end{array}$} \\
\hline & \multicolumn{3}{|c|}{ Domestic activities } & \multirow[t]{2}{*}{ Imports } & \multirow[t]{2}{*}{ Total } \\
\hline & Agriculture & Industry & Non-tradables & & \\
\hline Agriculture & 13.1 & 22.7 & 48.8 & 15.4 & 100 \\
\hline Industry & 9.7 & 21.0 & 48.6 & 20.7 & 100 \\
\hline Non-tradables & 11.6 & 24.5 & 47.7 & 16.1 & 100 \\
\hline Exports & 48.5 & 6.2 & 9.0 & & \\
\hline Total & 22.2 & 24.8 & 53.0 & 17.1 & 100 \\
\hline
\end{tabular}




\begin{tabular}{|c|c|c|c|c|c|}
\hline \multicolumn{6}{|c|}{$\begin{array}{c}\text { Table } 6 \\
\begin{array}{l}\text { Income and expenditure by sector of economic activity after } 60 \text { time periods following the } \\
\text { increase in exports of } 1,000\end{array}\end{array}$} \\
\hline \multirow[t]{3}{*}{ Income } & \multicolumn{5}{|c|}{ Expenditure } \\
\hline & \multicolumn{3}{|c|}{ Domestic activities } & Imports & Total \\
\hline & Agriculture & Industry & Non-tradables & & \\
\hline Agriculture & 249 & 433 & 931 & 293 & 1,906 \\
\hline Industry & 177 & 385 & 890 & 379 & 1,831 \\
\hline Non-tradables & 480 & 1,013 & 1,974 & 667 & 4,134 \\
\hline Total & 906 & 1,831 & 3,795 & 1,339 & 7,871 \\
\hline
\end{tabular}

Source: On the basis of RP Vol. III, p. 255 and pp. 264-266.

\begin{tabular}{|c|c|c|c|c|c|}
\hline \multirow{2}{*}{ Income } & \multicolumn{5}{|c|}{$\begin{array}{c}\text { Table } 7 \\
\text { Total and final income and expenditure by sector of economic activity after } \\
60 \text { time periods following the increase in exports of 1,000 } \\
\text { Income=expenditure= 22,910 and imports = exports= 3,339 }\end{array}$} \\
\hline & $\begin{array}{c}\text { Domestic } \\
\text { activities }\end{array}$ & & & Imports & Total \\
\hline & Agriculture & Industry & Non-tradables & & \\
\hline Agriculture & 589 & 1,023 & 2,201 & 693 & 4,506 \\
\hline Industry & 457 & 995 & 2,300 & 979 & 4,731 \\
\hline Other & 1,200 & 2,533 & 4,934 & 1,667 & 10,334 \\
\hline Exports & 2,260 & 180 & 899 & & 3,339 \\
\hline Total & 4,506 & 4,731 & 10,334 & 3,339 & 22,910 \\
\hline
\end{tabular}

Source: On the basis of RP Vol. III, p. 255 and pp. 264-266.

As can be deduced from this example the effect of the coefficient of expansion is limited on the one hand by the propensity to import which correspond to the leakages in the simple foreign trade multiplier analysis. ('the quantity of money lost in each trade for import payment'). In this example it is equal to roughly 0.17 on average for the three sectors $(15 \%, 20 \%$ and $16 \%$ for agriculture, industry and non-tradables respectively). A simple simulation exercise doubling the import propensity from 0.17 to 0.34 on average results in a commensurate decrease in the level expenditure (equal income) by $50 \%$ (from 7,865 to 3,960 monetary units). 
Figure 4: Simulation of rise in expenditure using an average propensity to import of 0.17 and 0.34 .

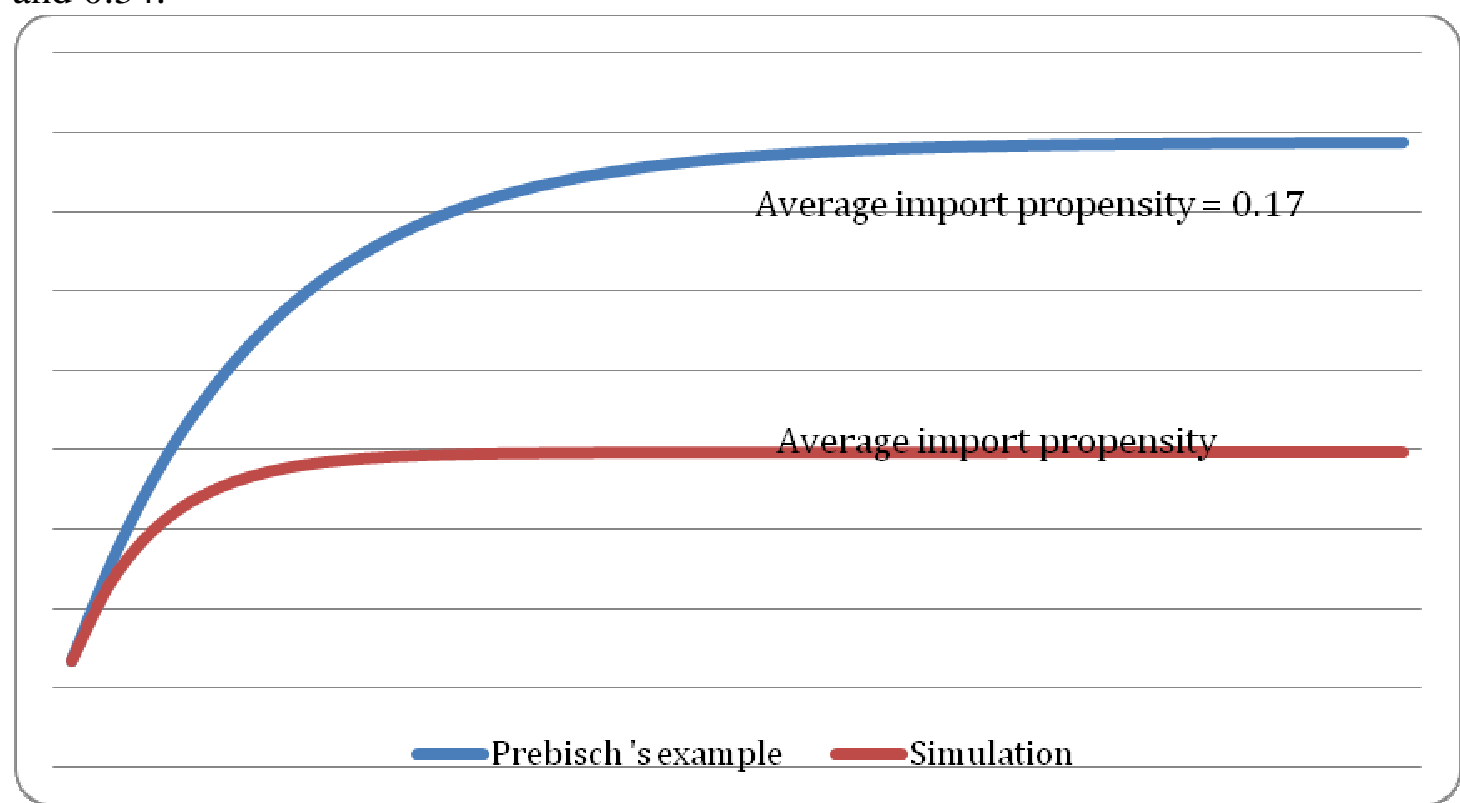

Source: Authors' own computations on the basis of RP Vol. III, p. 255 and pp. 264-266.

The other limiting factor Prebisch identified is the circulation velocity of money ('the number of times money changes hands'). The fact that the effectiveness and potency of the coefficient of expansion was limited by the propensity to import and the circulation velocity of money led him to distinguish his 'coefficient of expansion' from Keynes' 'multiplier' as set out in the GT. ${ }^{41}$

Prebisch, saw the multiplier effect as being explained by Keynes only for a closed economy with marginal references to the import propensity, with no reference to the circulation velocity of money and limited mainly in its effects by the savings propensity, "which constrains the expansion of economic activity and conspires against the full employment of resources" (RP, Vol. III, p. 359).

In the GT, Keynes was mainly concerned with an entrepreneur economy and with the process of decision making under uncertainty. In this sense the multiplier analysis appears in fact in a superficial and perhaps incomplete form (e.g. Khan (1984, p. 134); Chick (1997, pp.162-184)). Nonetheless, he was well aware of the effects of the propensity to import on the multiplier as illustrated by the reasoning underlying his estimate of Britain's multiplier and the comparison to that of the United States (GT, pp.121-122). ${ }^{42}$

\footnotetext{
${ }^{41}$ John Maurice Clark also emphasized the importance of monetary circulation for the working of the multiplier process (Fiorito and Vernengo, 2009).

${ }^{42}$ Keynes writings denote an important concern with the external sector and in fact in the GT he argued that the lack of concern with the external position of a country was a by-product of laissez-faire. As he put it (GT, p. 339): “...the weight of my criticism is direct against the inadequacy of the theoretical foundations of the laissez-faire doctrine upon which I was brought up... against the notion that the rate of interest and
} 
This follows from the fact that the propensity to import was part of the framework and indeed logic with which the multiplier was conceived (Khan, 1931 and 1933). Imports along with savings and 'the non-transfer portion of the income of the unemployed', was considered a leakage, and leakages ensured that the multiplier could be expressed as an infinite but converging geometrical series. Accordingly Keynes' 'Means to Prosperity' (1933) published three years prior to the GT which deals with an open economy, fully incorporates the propensity to import as part of the multiplier analysis presented. Moreover, by that time, treatments of the foreign trade multiplier could be found in Giblin (1930), Warming (1932), Kalecki (1933), and Harrod (1933) (which was fully incorporated into Keynes' theory of effective demand by 1939). ${ }^{43}$ By 1941, roughly three years prior to Prebisch's full treatment of the export expansion coefficient, the foreign trade multiplier was a well-established concept in the literature (Haberler, 1952).

Note that in the example provided by Prebisch above, as in others provided by him, incomes are eventually fully spent domestically or externally through imports. As a result, the marginal propensity to save (s) is ultimately equal to zero and the effect of a change of exports $(\mathrm{X})$ on expenditure $(\mathrm{Y})$ is reduced to the inverse of the marginal propensity to import $(\mathrm{m})$ or to the foreign trade multiplier. Hence, the increase in income is thus determined by the rise in exports times the foreign trade multiplier. Formally:

(1) $\mathrm{k}=1 /(1-\mathrm{c}+\mathrm{m}) \Leftrightarrow 1 /(\mathrm{s}+\mathrm{m})$; given $\mathrm{s}=0=>\mathrm{k}=1 / \mathrm{m}$

Where,

$\mathrm{k}=$ multiplier.

$\mathrm{c}=$ marginal propensity to consume.

The use of eq. (1) to determine the increase in income brought about by an autonomous change in exports yields,

(2) $\Delta Y=1 / m \Delta X \Leftrightarrow(\Delta Y / \Delta X)=1 / m$

In the example provided by Prebisch presented in tables 5-7 above, $\mathrm{m}=0.17, \Delta \mathrm{X}$ $=1,339$ and $\Delta Y=7,871$, or in other words,

(3) $\left.\Delta \mathrm{Y}=7,871=1 / \mathrm{m} \Delta \mathrm{X}=(1 / 0.17)^{*} 1,339\right)^{44}$

the volume of investment are self-adjusting at the optimum level, so that preoccupation with the balance of trade is a waste of time" (GT, p.339).

${ }^{43}$ See, King (1998). Harberler ((1941) [1952]) traces the marginal propensity to import to Paish (1914).

44 See, Fernández-López (1996). Thirlwall and McCombie (1994) have revived Harrod's foreign trade multiplier in the current literature dynamically as a growth theory, and more precisely as a Balance-ofPayments-Constraint (BPC) approach to growth. Putting aside the static versus dynamic differences in Prebisch and Thirlwall their approach is very similar. In both cases the level or growth of output determined is consistent with balance-of-payments (trade) equilibrium. Prebisch's derivation can easily be made 'dynamic' and turned into a BPC growth theory simply by assuming 'normal multiplicative' import and export demand functions as in Thirlwall and McCombie (ibid) and this would not alter in any way his reasoning. 
As mentioned above, besides the propensity to import, Prebisch identified the circulation velocity of money as the other key variable absent from Keynes' GT multiplier analysis allowing him to draw a distinction between his approach and that of Keynes. Prior to the publication of the GT, J.M. Clark (1935a) had made the distinction between (p.16): “...two approaches, one via successive cycles of income and spending by ultimate recipients of income, the other via the volume of money and its velocity of circulation. The first has been...developed by...Kahn... and J.M. Keynes; the second has, so far as I am aware, not found its way into print."

Following upon, J.M. Clark's distinction, some authors have argued that the logic of the multiplier implicitly includes assumptions regarding the behavior of the circulation velocity of money and that the analysis is incomplete without its explicit incorporation into the analysis. Haberler ([1937], 1952, p. 232) pointed out that to determine the secondary effects of new public expenditure, information was needed about the marginal propensity to consume and the circulation velocity of money. Machlup (1939) argued that the time element is 'of great importance' to the theory of the multiplier and introduced period analysis to work out the primary and secondary effects of public works spending, where periods are seen as reciprocals of the circulation velocity of money. Prebisch seems to hold a similar view as he argues (RP Vol. III, p. 359) that following an increase in income primary employment will expand but that this will not give to an expansion in secondary increased employment unless there is another round of new expenditure or unless the circulation velocity of money increases.

However, the reconciliation of both approaches is problematic. ${ }^{45}$ The circulation velocity of money is a purely expenditure approach emphasizing only aggregate demand and exchange. As part of the quantity theory framework and a central component of monetary cycle theories, it assumes full employment and thus postulates that supply correctly anticipates demand. This view negates the production side of the multiplier, an important part of Keynes' approach, as well as the role played by uncertainty in his theory.

\section{Money, the cycle and economic policy}

For the most part until 1931, the action of the government and the monetary and financial system during the upswings and downswings of the Argentine economic cycle had been pro-cyclical. This stance was easily justifiable since the business cycle was a 'natural', recurrent and predictable phenomenon with inevitable symmetrical upward and downward phases. Moreover as emphasized in an earlier section, avoiding downturns through artificial made the adjustment harsher.

The first policy reactions to the Great Depression did not constitute an exception. On the monetary front, the prevailing ideas, including those of Prebisch at the time, argued in favor of undertaking severe stabilization and adjustment measures to put the country, which in spite of its contractionary effects in the short run, on a ready stand to take advantage of the inevitable up-coming recovery. On the fiscal front a similar logic dictated the reduction of public salaries and State expenditures and the paralysis of public

\footnotetext{
${ }^{45}$ See, Clark (1935a; 1935b), and the correspondence between Clark and Hansen (1934) and Clark and Samuelson (1953) reproduced in Fiorito (2001). Also see Archibald (1956) and Lutz (1955).
} 
works (RP, Vol. IV, p. 116-117). ${ }^{46}$ Moreover, the greater were the excesses during the upswing of the business cycle, the more intense was the contraction in the downward phase of the cycle.

Since the cycle was bound to occur, the role of policy was limited and could at most ensure the orderly occurrence of its phases. On the one hand, policy could avoid the excesses of the boom (upward phase) including the characteristic processes of speculation and over-indebtedness, since the greater the excesses of the boom (in the upward phase) the harsher would be the following inevitable contraction. On the other hand, it could mitigate the effects of the downward phase on business conditions and real activity. ${ }^{47}$

A necessary condition to allow policy to play this role was the abandonment of the Gold Standard, which tended to aggravate the amplitude of the phases of the cycle making it more unstable. Prebisch identified three key weaknesses of the Gold Standard. First, its workings required the unnecessary contraction of imports at the same time as that of internal activities. Second, the natural trend for banks was to increase their lending in the ascending phase of the cycle contributing to exaggerate the amplitude of the boom (expansionary) phase and the contraction in the downward phase. Third, that the stability of the exchange rates under a gold standard regime contributed to stimulate quick silver capital inflows aggravating the phases of the economic cycle (RP, Vol. III, pp. 233-242; Vol. II, pp. 565-575; Vol. IV, p.141). Linked to these criticisms, was the argument that metallic currency regimes such as the Conversion Caisse were 'fair weather boards,' giving an appearance of smooth functioning in good times as capital flowed yet requiring in fact violent deflations in bad times when capital flowed out (RP, Vol. III, p.4 and Vol. I).

The abandonment of the Gold Standard in Argentina in 1929, introduced the possibility of tinkering with discretionary policy measures to smooth out the fluctuations of the economic cycle. However, these measures did not have their intended consequences as these increased the instability and flimsy foundations of the current conditions. It would become obvious that managing, to the extent of the possible, the fluctuations of the economic cycle required a strong, central and independent monetary authority.

At first to avoid the depreciation of the currency the government decided to export significant quantities of gold, reducing its supply thus raising the foreign exchange price of the currency. The consequent effect of the reduction of domestic gold supply on money supply, credit and in general liquidity conditions forced the introduction of the rediscount (RP, Vol. III, p. 4 and p.89; Vol. IV. p. 138).

The idea of using the rediscount was actually devised but not implemented in 1914 (RP, Vol. I, p. 173). In April 1931 Prebisch suggested its use with the aim of resorting banks liquidity to pursue their day-to-day operations and confront their immediate obligations avoiding the recourse to a brisk credit contraction and avoid a financial crash. The rediscount was not created to be used to stimulate new business or

\footnotetext{
${ }^{46}$ As Under Secretary of Finance, Prebisch implemented what he himself termed 'brutal budget adjustments' including a 15\% reduction in government wages. See, Pollock et al. (2002, p. 543).

47 This type of measures should be distinguished from those aimed at prolonging in an unnecessary fashion the boom (expansion). See, RP, Vol. I. p.123.
} 
expand new ones and certainly not to spur or facilitate long term-investment (RP, Vol. II, p. 2., Vol. III, p.89 and Vol. IV, pp. 118-119).

The use of the rediscount was followed by the imposition of exchange controls to countenance fears of further exchange rate depreciation due to Great Britain's departure from the Gold Standard regime in October 1931(RP Vol. II, pp. 4-6). The imposition of exchange controls lasted from October 1931 until towards the end of 1933 and fixed the value of the peso at an artificially high value. The consequences were to further the external imbalance and the decline in agriculture and industrial prices thus aggravating the effects of the Great Depression including that of growing unemployment and expanding debt. The measures also provided the incentives for the creation of a foreign exchange black market (RP, Vol. III pp.16-17).

Eventually the pernicious unintended effects of these measures led to a change in the monetary stance in 1933 consisting of a combination of exchange rate devaluation coupled with the establishment of a dual exchange rate system consisting of an official (affecting the export of traditional products) and market based exchange rate and the imposition of import permits (See table 8 in the annex for a more detailed description of these measures). ${ }^{48}$

Prebisch would later sustain that foreign exchange and import controls had been successful in helping to restore the external equilibrium in 1933. He passed a similar judgment on similar measures applied in 1937, and in period running from 1938 to 1940 also stating that these measures provided a way to stimulate domestic industry (RP, Vol. IV. p.194). Probably this experience coupled with the analysis of the foreign trade multiplier (see Eq.(2) above) constituted important steps leading towards his proposal of reducing the 'import coefficient' as one of key pillars of his later policy proposal to achieve 'general economic growth' (ibid, Vol. IV pp.207-215).

Prebisch argued that the use of discretionary measures such as the re-discount, notwithstanding its lack of success, and exchange controls paved the way for the creation of the Central Bank in 1935, although he claims that he had seen the need to create a central monetary authority before WWI. As he puts it (RP, Vol. II, p. 7. Note):

"When I was at the Banco de la Nación as Director of Economic Research I realized that the Conversion Caisse did not function, that it functioned when gold flowed in the country and ceased to function when gold flowed out of the country, and that a fundamental reform was necessary. This, before the great crisis. I began to roam in my head the idea of the creation of an Argentine Central Bank. When

\footnotetext{
${ }^{48}$ During this time also are seen from Prebisch's views the first attempts, although tepid and temporary, at countercyclical policy. These consisted in sustaining the price of agricultural goods through government purchases, and the undertaken of public works. No doubt the influence of J.M. Keynes' Means to Prosperity, which Prebisch had read in 1993 was paramount in the design of these measures (RP, Vol. II, p. 146, Note). In his interview with Prebisch in 1983, Julio González del Solar (apud Mallorquin, 2006) terms the use of the rediscount and the creation of the Commission for Foreign Exchange Control in 1931 the first two heterodox steps in Prebisch's thinking. However, as explained above the rediscount was an old idea and Prebisch himself considered it an orthodox instrument. He viewed exchange controls as somewhat of a departure from the mainstream doctrine (RP, Vol. III, p. 89). See also, Prebisch (1984, p.175). Curiously later on in 1946, he claimed to be in disagreement and 'abominate' restrictions including exchange rate controls but justified their use on the grounds that developing countries did not possess alternative instruments to confront and mitigate the effects of the business cycle (See, RP, Vol. IV., p. 226).
} 
the crisis came it was necessary to take emergency measures, and that convinced me even more that a Central Bank was necessary; that the rediscount could not be applied, without a previous organization; that it was necessary to articulate that with a series of other instruments, and that was the Central Bank."

The Central Bank of Argentina saw the light in 1935. The project for the bank was drafted by Prebisch himself in 1934 at the request of the minister of finance Federico Pinedo. ${ }^{49}$ It was conceived as an institution independent of the government ('It is not conceivable that a Central Bank be managed by governments' $)^{50}$ permitting a more rational distribution of monetary functions and more efficient management of reserves, whose main objective was monetary stability, along conventional lines.

To this end, Prebisch thought that the Central Bank had a role to play in cushioning the effects of the economic cycles although he found illusory to think that it could offset the movements of the cycle. As he put it: (RP, Vol. II, p. 64) "To expect that ondulatory movements in the economic activity of the country can be offset by the excellence of a monetary system would be to fall in the same illusion harbored by many economists of the United States with respect to the Federal Reserve, prior...to the...collapse. But it cannot be doubted that the amplitude of those movements could be cushioned by an efficiently run Central Bank." ${ }^{21}$

It is important to understand that the cushioning of the fluctuations of the business cycle did not respond to the objective of maintaining domestic output stability but rather to that of maintaining the stability of prices and that of money. It is in this sense that the lean-against the wind monetary policy was in essence of an orthodox nature (see, RP, Vol. III, p. 90).

The lean against the wind monetary policy was reflected in one of the key objectives of the Central Bank as set out in Prebisch's 1934 project was to ensure an adequate level of reserve accumulation as a precautionary motive of building buffer stocks to confront export shocks and sudden capital stops. As he put it (RP, Vol. II, p. 610-111): "The ascending movements are, in general, of a limited duration. The opportunity to repair the consequences of past wrongs and accumulate reserves for difficult times, whose return it is prudent to foresee, should not be then undermined."

As such, the first article of project proposal for the creation of a Central Bank in Argentina dealing with its functions stated: (ibid, p. 383) "The Bank will have as objective: a) The concentration of sufficient reserves to moderate the consequences of fluctuations in exports and the investments of foreign capital, on money, credit, commercial activities, in order to maintain the value of money.",52

\footnotetext{
${ }^{49} \mathrm{He}$ had been bestowed the same task earlier in 1931 by the then minister of finance Enrique Uriburu. See, RP, Vol. II. Notes to pp. 7 and 351.

${ }^{50}$ The independence of the Central Banks was seen by Prebisch as a protection against the temptation to inflate the currency due to fiscal imbalances (RP Vol. II, p. 363).

${ }^{51}$ See also ibid. p.358 for a similar statement and p. 664-665.

${ }^{52}$ In his International Currency Experience (1944, pp. 85 and 194), Nurske thought highly successful the policy of neutralization, mainly international reserve accumulation, pursued by the Argentinean Central Bank. Triffin also entertained a similar opinion praising also non-orthodox instruments such as foreign exchange controls. Following a similar line of thought, in 1945, Prebisch helped to draft the legislation for the newly created Central Bank of Paraguay and the reform to the existing system of foreign exchange controls. See, Helleiner (2009).
} 
Following the creation of the Central Bank, the Argentine economy experienced an expansion in economic activity lasting until 1937. During this time the Central Bank, in line with the orthodox spirit of its creation, used open-market operations, interventions in the foreign exchange market and moral suasion to avoid an over expansion and overheat of the economy (See, ibid, p.64 and 359, pp. 610-622; RP, Vol. III, pp. 88-119).

However, the force of events prompted by the beginning of the downward phase of the cycle in 1937, led the bank to progressively evolve into a less orthodox institution whose goal became more ambitious than just 'cushioning' the phases of the business cycle to ensure their orderly occurrence and maintain the stability of money. The Central Bank became aware that it had a double objective, price and output stability, and that the balance of payments was central for both.

Initially in 1937, "the Central Bank...was predisposed to consider this contraction of domestic economic activity as a logical and natural event, indispensable to reduce imports and establish the equilibrium in the balance of payments" (RP Vol. III, pp.101102). Yet, as the contractionary effects wrecked havoc, the Central Bank decided to change and stabilize domestic activity. According to the 1938 Central Bank Report (RP, Vol. III, p. 104):

"... monetary policy can propose two objectives in the face of the economic cycle. The first consists in avoiding that the expansion of credit accentuates the intensity of ondulatory movement... The second objective goes further. It is not limited to avoid the aggravation of these fluctuations, but it proposes (se propone) furthermore to limit its amplitude and reduce the intensity of the variation of purchasing power during the cycle, in order to attenuate the consequences of its variations on the volume of domestic economic activity."

The need for countercyclical action resurfaced soon after the start of World War II, as Argentina was faced with a growing external imbalance, and the "perception of decline in business activity and in particular in the construction sector" leading to a fear of general economic prostration (RP Vol. IV, p. 156-157). The plan for countercyclical action (The Plan for National Reactivation) contemplated an expansionary monetary policy coupled with exchange rate controls. More specifically, the plan sought to purchase agricultural surpluses to avoid price declines, increase construction activity and promote the finance of industrial development. However, at the same time the government planned a significant contraction in expenditure through the reduction of public wages and salaries and employment and public works.

The combination of an expansionary monetary policy and contractionary fiscal policy is not viewed as a contradiction. Rather, it is defended on the basis that the reduction in public expenditure will widen the space for private action and the workings of the free market. This variant of the 'crowding-out' argument highlights how attached the Argentine authorities remained to orthodox economic thinking.

The Plan for National Reactivation was never approved. The force of events superseded it and, in particular, by the war effort of the United States which led to an increase in internal demand and imports. As put by Prebisch (RP Vol. IV. p. 160): "The United States, which in 1940 had been absent in the market of certain Argentine products, starts to purchase very activity. This soothes our balance of payments concerns, allows a 
more flexible distribution of foreign exchange, increases domestic purchasing power and rapidly changes the context of the situation."

The change in external conditions led to the suppression of import permits and the flexibilization of the exchange rate regime, even though a dual exchange rate remained in place. It is also important to note that in 1943 the central bank imposed capital controls to deter the inflow short-term capital and avoid its destabilizing effects and stimulate foreign direct investment. While this measure was in force only for three months, it is worth quoting Prebisch at length due to its current relevance (RP Vol. IV, p. 183):

"This capital [short-term capital] went to further inflate the categories of goods or assets that were already inflated, and did not translate, except in very rare occasions, in a real increase in the production of the country... the measures adopted by the government allow to make an exception, to allow the inflow of these capitals if it is shown that these are oriented towards the increase in real production..." 53

\section{The quest for national policy autonomy and the global economic cycle}

Prebisch viewed the change in external conditions after the start of WWII and its effects on Argentina as a validation of his business cycle approach. The business cycle and its phases was a recurrent and natural phenomenon. The phases were related and the more exaggerated was the boom (expansionary) phase the sharper would be the contraction. The change from boom (expansionary) to bust (contractionary) conditions occurred rapidly and unpredictably requiring flexibility in economic policy and more importantly moderation and prudence, and an active policy of neutralization. ${ }^{54}$

While he did recommend avoiding excessive fiscal spending and lax monetary policies, and increased savings during the boom (expansion) to face and weather the inevitable following contraction he argued that a country like Argentina should not be forced to forego higher growth and improved material well being during the upward phase of the cycle, only to face to consequences of a downturn.

He ultimately recommended shielding the domestic economy from the ups and downs by a process of substitution of domestic industry and production for foreign imports. This was a basis for arguing for the promotion and development of domestic industry and the expansion of internal activity.

These ideas were already embedded in his book proposal Money and Economic Activity on which he began working in 1943, the year in which as a result of a military coup marking the eventual ascendancy of Peronism, Prebisch lost the position in the

\footnotetext{
${ }^{53}$ In Latin America, and elsewhere, proponents of capital controls base their case precisely on the argument put forward by Prebisch, that is, the change in the composition of financial inflows from short-term to longterm investment.

${ }^{54}$ As he explains: "We are exposed, in our country, to rapid and unpredictable changes in the economic situation. We pass in a few months of transition from a moment of somber perspectives, such as in 1940, to the opposite situation...It suffices to reflect on what would have happened if the plan for construction [under the National Plan for Reactivation] would have been launched and to the resulting purchasing power would have been added a new purchasing power derived from the increase in exports: circulation would have expanded in an exaggerated manner, with the pernicious consequence that always follow"(Vol. IV, p.160).
} 
administration, including his Central Bank appointment, that had been essential for the development of his ideas since the early 1930s. ${ }^{55}$

In Money and Economic Activity, he argued that monetary and financial policy should have three main aims: (i) attenuate the incidences of the abrupt changes in harvest conditions and the fluctuations and external contingencies; (ii) create the monetary conditions that stimulate the development and maintenance of full employment of the working force; (iii) foster and support the highest possible rate of growth of economic activity. ${ }^{56}$

The successful achievement of these policies required an imports policy and a fiscal reform. The imports policy consisted in 'the rational modification of their composition to serve certain objectives' rather than their systematic restrictions.' Prebisch thought that a policy of autarky was as absurd as a policy of free trade and agreed that Argentina should participate to the extent of the possible in the international economy but to avoid a 'constant subordination of the national economy to external movements and contingencies,' the country needed to 'develop inwardly, strengthening its internal structure and achieve an autonomous functioning of its economy.' 57

Prebisch's defense of national policy autonomy eventually took on a regional tone, as he became convinced that the Argentinean cycle and its features were not specific to Argentina but that they were rather the manifestations and characteristics of the workings of a global process, a universal cycle. In this sense that Prebisch argued, as mentioned above, that the Argentine cycle was a mirror, a reflection, of external of the international monetary cycle.

The global or universal cycle was triggered by developed countries and more specifically by what he termed to be the cyclical center. The cyclical center referred to the country (perhaps group of countries) whose economic repercussions due its importance were transmitted to the rest of the world. In the nineteenth and up until WWI, Great Britain held the cyclical center title only to be taken by the United States thereafter. The countries subject to the influence of the impulses of the center, the periphery, included all Latin American countries. As Prebisch put it (RP, Vol. IV, p.224):

\footnotetext{
${ }^{55}$ Following his demise from the Central Bank in 1943 and until his ECLA appointment he remained committed to teaching and was also an international consultant. According to him, he began at this time rethinking his past experiences and developing his periphery-center and development theories. See Pollock et al. (2002, p. 549).

${ }^{56}$ Note that contrary to mainstream theory and practice inflation and more specifically, a low and stable rate of inflation is not included, as part of the aims of monetary policy. Nonetheless, maintaining full employment and the highest possible rate of growth of output do inevitable lead to situations of inflation and output trade-offs. Throughout the period covered in this article Prebisch never abandoned the orthodox belief that inflation is the product of fiscal deficits. See for example RP. Vol. IV, p. 229.

${ }^{57}$ See Prebisch (1943, p. 7; RP. Vol. IV pp. 209-214). In line with the Balance-of-Payments approach he argued that a country like Argentina needed to import in order to export. Had Prebisch been aware that in his framework, formalized in part by Eq.2, above exports $(\mathrm{X})$ can equal the propensity to export times the level of external demand (or income), as in McCombie and A.P. Thirlwall (1994), he could have been a step away from realizing that a policy for general of economic growth, could be based, partly, on the reduction in the import coefficient, on an increase in the export coefficient or in a combination of both. The reduction in the import coefficient may well be conceived alternatively as in an increase in the productivity of imports. In many respects the simple numerical example presented in the section on the Coefficient of expansion and the foreign trade multiplier above prefigures the literature on the balance of payments constraint to growth.
} 
"The United States...fulfills the role of the main cyclical center, not only within the continent but also in the world: and the Latin American countries are in the periphery of the economic system.... Why do I call the United States, the cyclical center? Because from this country, given its magnitude and economic characteristics, start the expansionary and contractionary impulses of world economic life and particularly those of the Latin American periphery, whose countries are under the influence of those impulses just as they been had before, when Great Britain had the role of main cyclical center." 58

The universal or global cycle was thus divided into two phases with different characteristics, one affecting the center and the other, the periphery, that is, Latin American countries. ${ }^{59}$ Moreover, since the periphery faced a binding external constraint while the center did not, they faced markedly different restrictions in their use of domestic policy space.

Faced with a contraction of economic activity and price declines the cyclical center could always resort to the use of monetary instruments such as the money supply or interest rates without regard for exchange rate parity or international reserve adequacy conditions. ${ }^{60}$ Contrarily, the periphery, bereft of the use of this privilege by the binding character of its external constraint, had to turn to the use of exchange rate variations or quantitative restrictions and controls (RP, Vol. IV. pp. 225-226).

Prebisch also contemplated a policy of reserve accumulation by the countries of the periphery. In fact he argued, very much in line with his earlier views, that the countries of the periphery had 'the responsibility' to generate the financial resources during the upward phase of the cycle (including international reserves) to face and weather contractions (Vol. IV. p.232).

Prebisch also thought that the White and Keynes plans for a new international order had great merit in their proposal of a credit system allowing temporary alleviations of balance of payments imbalances. However, according to him, they failed to address the more fundamental problem of creating a balanced and equitable trading system. ${ }^{61}$

As he progressed on his cycle thought processes Prebisch continued to underscore the relevance of a general cycle theory but argued that a cycle theory must converge towards a more general 'dynamic theory.' Prebisch understood that the growth process of a capitalist economy was that of a growth cycle and that this process embedded the entire spectrum of economic activity. In his own words (RP, Vol. IV, p. 414):

\footnotetext{
58 The center-periphery cycle dichotomy was a historical and evolutionary concept. Not all developed countries belonged to the center. Indeed, Prebisch asked himself if Canada should be part of the periphery or of the center. Also, besides a main cyclical center Prebisch introduced the notion of second cyclical center a role he attributed to Great Britain. See RP, Vol. IV.pp.224-231.

${ }^{59}$ Prebisch did not develop the different phase characteristics of the center and periphery.

${ }^{60}$ This is remindful of debate surrounding the policy of quantitative easing pursued since 2008 by the Federal Reserve Bank of the United States.

${ }^{61}$ As he put it (Prebisch, 1943, pp.8-9): “...in spite of their great merits they [the Keynes and White plans] do not resolve the fundamental problem that depends essentially on the restoration of international trade. If the United States does not buy as much from the rest of the world as the world buys from the United States there is no monetary system that will resist in the long run..."
} 
"Each time I am more convinced that the cycle is the way through which a capitalist economy grows. A capitalist economy expands only in wave motion and any perturbation...can only give rise to a wave motion movement. ...If the cycle is the way to grow... and if the economy moves incessantly in this manner, it would seem that all the joint events of the economy, not only those of production and employment, but also those of distribution, must be integrated into a general dynamic theory."

Prebisch's outlined his dynamic economic theory in 1949 but it remained at the level of a series of lectures notes and conferences. Nonetheless, it included, albeit at a rough stage, besides the center-periphery dichotomy, and the ideas that the main constraint to economic expansion in the periphery was the balance of payments, the workings of technological progress in both development poles, as well as other notions and concepts that were key to justify state led industrialization and also regional integration, central tenets of his manifesto "The Economic Development of Latin America and Some of its Main Problems" and to $\operatorname{ECLA}(\mathrm{C})$ development thinking. 
Annex

\begin{tabular}{|c|c|c|c|}
\hline \multicolumn{4}{|r|}{$\begin{array}{l}\text { Table } 8 \\
\text { Some important features of the monetary regimes associated with Prebisch's cycles }\end{array}$} \\
\hline Cycles & Monetary Regime & Period & Features \\
\hline $\begin{array}{l}\text { Cycle } \\
\text { II }\end{array}$ & Conversion Caisse & $1867-1876$ & 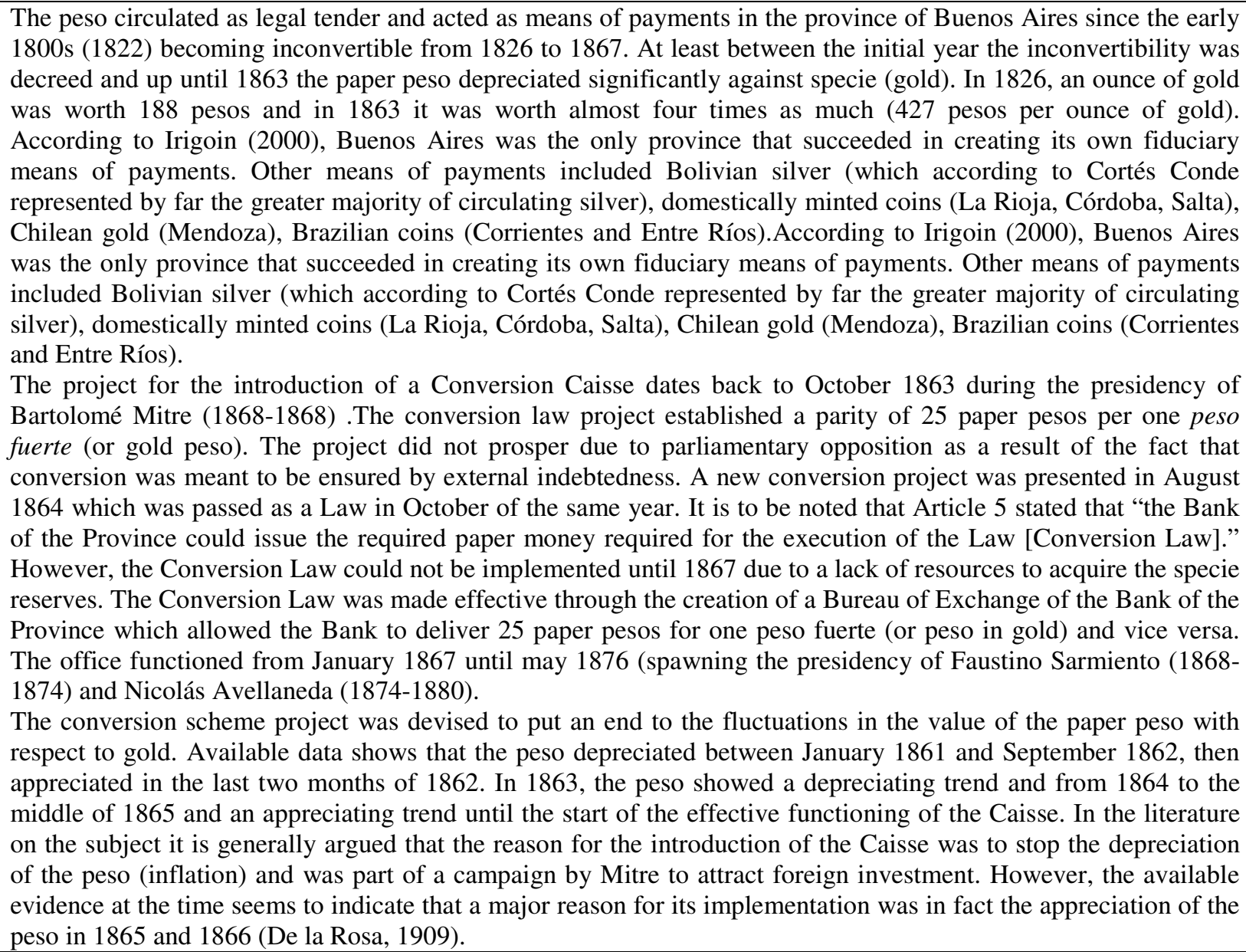 \\
\hline
\end{tabular}


Table 8 (Continued)

Some important features of the monetary regimes associated with Prebisch's cycles

\begin{tabular}{|c|c|c|c|}
\hline \multicolumn{4}{|r|}{ Some important features of the monetary regimes associated with Prebisch's cycles } \\
\hline Cycles & Monetary Regime & Period & 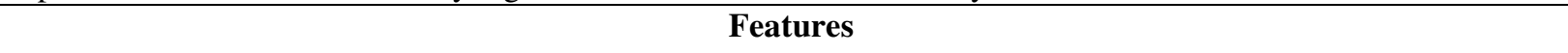 \\
\hline $\begin{array}{l}\text { Cycle } \\
\text { III }\end{array}$ & $\begin{array}{l}\text { Inconvertibility } \\
\text { Convertibility } \\
\text { Incovertibility }\end{array}$ & $1877-1886$ & $\begin{array}{l}\text { Convertibility is officially suspended in May } 1876 \text {. In September } 1876 \text { the metallic notes issued by the Bank of the } \\
\text { Province are declared legal tender. Between this time and } 1881 \text { the monetary landscape is one of disorder with no } \\
\text { national money. Provinces issued their own currency and the currency had different values 'between one province } \\
\text { and another and even between cities in the same province'. Also different varieties of paper, foreign coins and } \\
\text { foreign coins were in circulation. Convertible and inconvertible paper circulated in fact side by side. (Williams, } \\
1969 \text { [1920], pp. } 31-32 \text { ). In } 1881 \text {, J.J. Romero the finance minister of the then President Julio Argentina Roca } \\
\text { (1880-1886) presented a proposal for a bi-metallic standard of gold and silver pesos (of } 24.9 \text { grains and } 385.5 \\
\text { grains respectively) with a legal ratio of } 15.55 \text { between both ( } 385.5 / 24.9=15.5) \text {. The law established a mint (Casa } \\
\text { de Moneda) and decreed the issue of eight million gold pesos and four million silver pesos (according to Prebisch, } \\
\text { Vol. I. p. 137, the limited coinage of silver relative to gold pesos implied that the new system was in fact } \\
\text { monometallic. Once issued to their full amount the circulation of foreign coins as legal tender was to be prohibited. } \\
\text { Nonetheless, these could be traded at their bullion value at the mint. The aim of the law was to create a national } \\
\text { currency and terminate the circulation of foreign coins. Prior to a series of measures aimed to retire coins from } \\
\text { circulation, the entry in force of the standard is dated to July } 1883 \text { ("An executive decree of August } 26,1822 \\
\text { required the provincial bank [Bank of the Province] to begin the conversion of its paper before July } 1,1883 \ldots \text { at a a } \\
\text { ratio of twenty-five of the old for one of the new." (Williamson, Ibid, p. } 34 \text { ). This was extended by law to all banks } \\
\text { of issue in October } 1883 \text {. In December } 1883 \text {, a period of six months was provided to fulfill the terms of the law. } \\
\text { Only five banks were allowed to issue new metallic coins. In spite of the creation of a Bureau of Inspection of } \\
\text { Banks to make sure banks complied, Banks did not redeem notes for gold. Gold was melted or exported and } \\
\text { inconvertibility was decreed in January } 1885 \text { for two years. }\end{array}$ \\
\hline
\end{tabular}




\begin{tabular}{|c|c|c|c|}
\hline \multicolumn{4}{|r|}{$\begin{array}{c}\text { Table } 8 \text { (Continued) } \\
\text { Some important features of the monetary regimes associated with Prebisch's cycles }\end{array}$} \\
\hline Cycles & Monetary Regime & Period & Features \\
\hline & Inconvertibility & $1885-1899$ & $\begin{array}{l}\text { The inconvertibility was decreed initially in } 1885 \text { for two years and suspended indefinitely in December of the next } \\
\text { year (Miguel Juarez Celman succeeded Roca as president of Argentina from } 1886 \text { to } 1890 \text { ). From } 1885 \text { to } 1899 \\
\text { The Argentine regime was on a paper standard and the peso floated freely against gold. The peso exchanged at a } \\
\text { discount against gold throughout this period. During this time several unsuccessful proposals to reduce the paper } \\
\text { money in circulation or to fix the gold-peso parity.were put forward including the creation of national treasury with } \\
\text { a conversion fund. Any attempt to return to a convertibility regime was made virtually impossible by the Law of } \\
\text { National Guaranteed Banks of Free Banking Law (Bancos Garantidos) passed in } 1887 \text { which opened the right of } \\
\text { issue to any bank fulfilling certain conditions. While the announced intention was the convertibility of the currency } \\
\text { and the provision of a uniform currency, Prebisch as other authors (i.e, Williamson) viewed it as a purely } \\
\text { inflationist measure (Vol. I., pp.148-152). The free banking scheme came to an end with the } 1890 \text { Baring Crisis. } \\
\text { In } 1890 \text {, the incoming president Carlos Pellegrini (1890-1892) decides to create a New Conversion Caisse to issue } \\
\text { notes and "effect the gradual conversion and amortization of the legal tender currency" (Artículo 1, Caja de } \\
\text { Conversión, Ley } 2741,7 \text { de Octubre } 1890 \text { ). The new conversion project also aimed at restoring the convertibility } \\
\text { of the peso at the par value with gold. The conversion project was not feasible because the country lacked the } \\
\text { required gold reserves even with the adoption of weaker parities. }\end{array}$ \\
\hline
\end{tabular}




\begin{tabular}{|c|c|c|c|}
\hline \multicolumn{4}{|r|}{$\begin{array}{c}\text { Table } 8 \text { (Continued) } \\
\text { Some important features of the monetary regimes associated with Prebisch's cycles }\end{array}$} \\
\hline Cycles & Monetary Regime & Period & Features \\
\hline $\begin{array}{l}\text { Cycle } \\
\text { IV }\end{array}$ & $\begin{array}{l}\text { Convertibilty } \\
\text { Conversion Caisse }\end{array}$ & 1903-1914 & 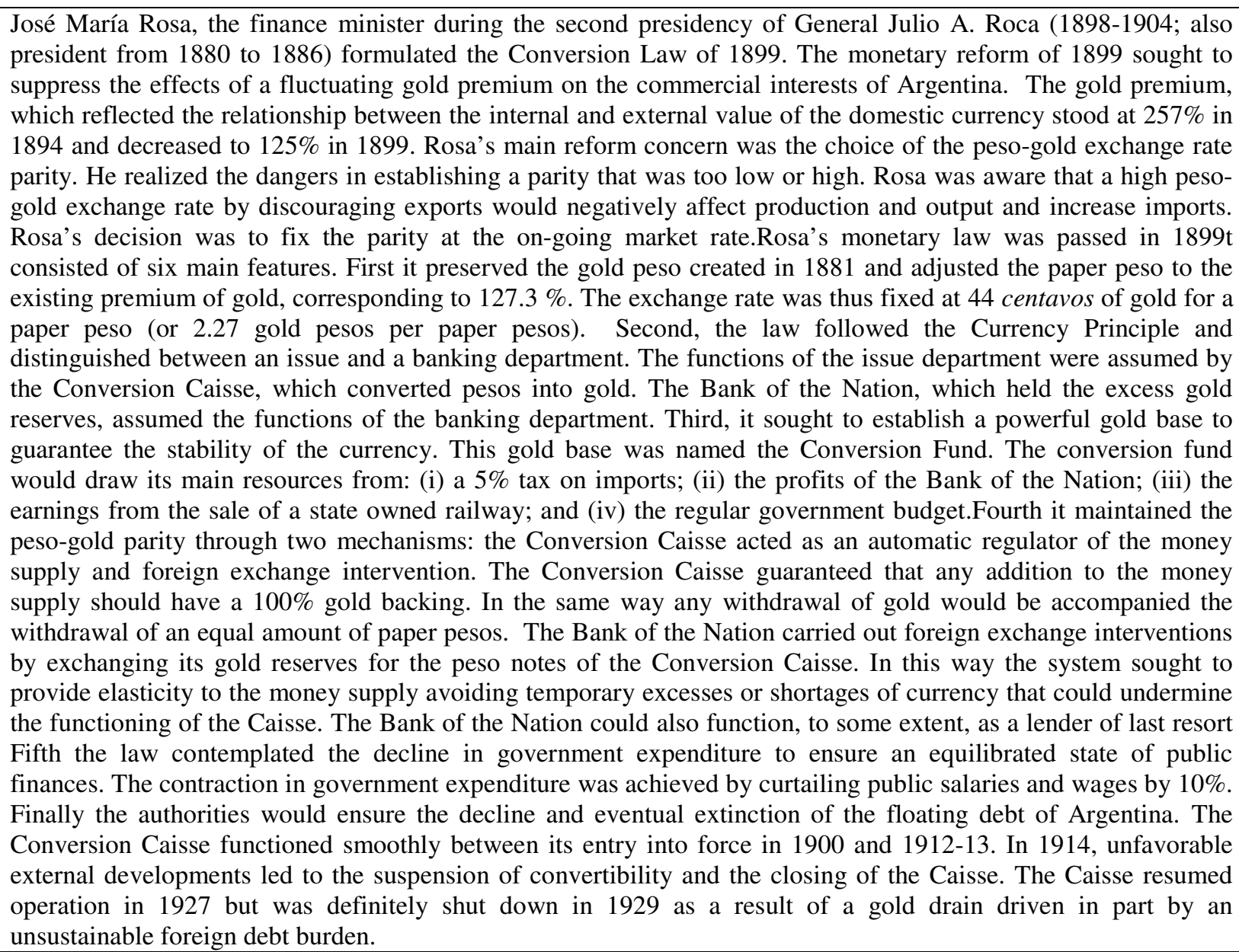 \\
\hline
\end{tabular}




\begin{tabular}{|c|c|c|c|}
\hline \multicolumn{4}{|r|}{$\begin{array}{c}\text { Table } 8 \text { (Continued) } \\
\text { Some important features of the monetary regimes associated with Prebisch's cycles }\end{array}$} \\
\hline Cycles & Monetary Regime & Period & Features \\
\hline $\begin{array}{l}\text { Cycle } \\
\text { V }\end{array}$ & $\begin{array}{l}\text { Convertibilty } \\
\text { Conversion Caisse } \\
\text { Inconvertibitly }\end{array}$ & $1927-1933$ & $\begin{array}{l}\text { The Caisse resumed operation in } 1927 \text { (at the } 2.27 \text { gold-peso parity) but was definitely shut down in } 1929 \text { as a } \\
\text { result of a gold drain driven in part by an unsustainable foreign debt burden. Paper currency becomes } \\
\text { inconvertible. Thereafter the conversion office continues to function but only for fiscal purposes. Also the } \\
\text { monetary authorities impose the use of the rediscount (April 1931) first dictated in } 1914 \text { through the Bank of the } \\
\text { Nation (Banco de la Nación) and establish exchange rate controls (October 1931). Finally import duties were } \\
\text { increased. The control of foreign exchange falls part under the scope of the Treasury through the management of } \\
\text { an incipient foreign exchange fund and partly under the scope of the Office for the Control of Exchanges (Oficina } \\
\text { de Control de Cambios). The latter regulates commercial banks exchange rate movements and also deals with } \\
\text { exporters and importers. Eventually in } 1932 \text { the peso exchange rate is fixed at undervalued parity with detrimental } \\
\text { consequences for the agricultural sector and exporters and leading to the creation of a foreign exchange black } \\
\text { market. In November } 1933 \text {, the government abandons the artificial peso parity and introduces a reform based on } \\
\text { import permits, a dual exchange rate system (whereby the majority of exports and imports conform to the official } \\
\text { exchange rate) and the establishment of a parity in accordance with market conditions. Federico Pinedo is } \\
\text { appointed minister of finance. Pinedo, under the Presidency of Agustín Pedro Justo (1932-1938), and instrumental } \\
\text { in the creation of the Argentine Central Bank, reforms the system of exchange controls from one based on open } \\
\text { auction operations (the government purchased foreign exchange from exporters and sold it in open auction) to a } \\
\text { system based on dual exchange rates. With the reform purchases of foreign exchange at the rate offered by the } \\
\text { government could be effected through a system of permits. Purchases of foreign exchange without permits were } \\
\text { allowed but at a premium (which was often above } 20 \% \text { that of the government rate (Rock, 1987)). }\end{array}$ \\
\hline $\begin{array}{l}\text { Cycle } \\
\text { VI }\end{array}$ & & 1935-1937 & $\begin{array}{l}\text { Creation of the Central Bank of Argentina. It "takes over all the assets and liabilities of the Conversion Office. } \\
\text { Revalues gold stock according to prevailing market rate of exchange (new par is } 4.96 \text { versus 2.27). Uses proceeds } \\
\text { to increase backing of money base, and to bail out the financial system" (Della Paolera and Taylor (2001) p.23). } \\
\text { The Central Bank of Argentina takes on the functions of the Conversion Caisse, the Treasury and those of the } \\
\text { Office for the Control of Exchanges (Oficina de Control de Cambios) (with the exception of the dealings with } \\
\text { exporters and importers). The Central Bank pursues discretionary countercyclical monetary policy embedded in the } \\
\text { absorption and sterilization of liquidity during the upward phase of the cycle and the injection of liquidity in the } \\
\text { downward phase. Eventually as will be explained in detail in section six, in } 1937 \text { the Central Bank deepens the use } \\
\text { of its countercyclical stance. The dual exchange rate system is still in force Central Bank also intervenes in the } \\
\text { foreign exchange market to act on expectations. Starting in } 1935 \text { import permits are not used as a general import } \\
\text { restriction mechanism but rather as a import selection tool affecting the composition of imports. }\end{array}$ \\
\hline
\end{tabular}




\begin{tabular}{|c|c|c|c|}
\hline \multicolumn{4}{|r|}{$\begin{array}{c}\text { Table } 8 \text { (Continued) } \\
\text { Some important features of the monetary regimes associated with Prebisch's cycles }\end{array}$} \\
\hline Cycles & Monetary Regime & Period & Features \\
\hline $\begin{array}{l}\text { Cycle } \\
\text { VII }\end{array}$ & & 1939-1944 & $\begin{array}{l}\text { The loss of reserves due to unfavorable external conditions following the start of World War II leads to the } \\
\text { imposition of new and added import controls and to modifications to the existing official foreign exchange rate } \\
\text { parity and to the bundle of goods falling under the official and floating exchange rate market. Establishment of a } \\
\text { Tendering regime for foreign exchange (Régimen de licitaciones de cambio) and the regime of the Corporation for } \\
\text { the Promotion of Trade (Corporación para la Promoción del Intercambio). } \\
\text { In 1940, favourable external conditions (expansion of exports, higher capital inflows) lead the Central Bank to } \\
\text { impose restrictions (capital controls) temporarily (these are in force for only three months) on short-term capital } \\
\text { inflows in 1943. Import permits are eliminated in 1941. The exchange regime is made more flexible although a } \\
\text { dual exchange rate regimes remains in place. }\end{array}$ \\
\hline
\end{tabular}




\section{References}

Agote, P.F. (1884) Informe...Sobre la Deuda Pública, Bancos y Emisiones de Papel Moneda, y Acuñación de Monedas de la República Argentina. Buenos Aires. Imprenta La Universidad de J.N. Klingelfuss, Calle Venezuela, No 234.

Amaral, S. (1984) "El Empréstito de Londres de 1824.” Desarrollo Económico, Vol. 23, No. 92. Pp. 559-588.

Arana, F. (1969) Historia Económica y Social Argentina. Buenos Aires: Editorial El Coloquio.

Archibald, G.C. (1956) Multiplier and Velocity Analysis: An Annulment Economica, Vol. 23, No. 91, pp. 265-269

Bordo, M. (1984) The Gold Standard: The Traditional Approach in M. Bordo and A. Schwartz Eds. A Retrospective on the Classical Gold Standard, 1821-1931. Chicago: The University of Chicago Press.

Bridel, P. (1987) Cambridge Monetary Thought: The Development of Saving-Investment Analysis from Marshall to Keynes. New York: MacMillan Press Ltd.

Caravaca, J. and Plotkin. M. (2007) "Crisis, ciencias sociales y elites estatales: La constitución del campo de los economistas estatales en la Argentina.’'Desarrollo Económico, Vol. 47, No. 187. pp.401-428.

Cerro, A. (2008) La conducta cíclica de la economía Argentina y el comportamiento del dinero en el ciclo económico. Argentina 1820-1998. Resumen del trabajo de tesis para acceder al Magister en Economía de la Universidad Nacional de Tucumán.

http://www.depeco.econo.unlp.edu.ar/jemi/1999/trabajo05.pdf

Chick, V. (1997) "The Multiplier and Finance" in A 'Second Edition' of The General Theory Vol. 1. Edited by G.H. Harcourt and P.A. Riach. New York: Routledge. Pp.164-182.

Clark J. M. (1935a). "Cumulative Effects in Aggregate Spending as Illustrated by Public Works,” American Economic Review, 25, 14-20.

Clark J. M. (1935b). Strategic Factors in Business Cycles. With an introduction by the Committee on Recent Economic Changes. New York: National Bureau of Economic Research in cooperation with the Committee on Recent Economic Changes.

Cortés Conde, R. (2001) "Raúl Prebisch: Los años de gobierno”. Revista de la CEPAL 75. pp. 83-87.

Cortés Conde, R. (1997) La Economía Argentina en el Largo Plazo. Buenos Aires: Editorial Sudamericana. 
Cortés Conde, R. (1994) Deuda Externa y Crisis en Argentina 1860-1905 en La formación de los bancos centrales en España y América Latina (Siglos XIX y XX). Vol. II: Suramérica y el Caribe. Pedro Tedde y Carlos Marichal (coords.). Banco de España-Servicio de Estudios. Estudios de Historia Económica, No. 30.

Di Tella G. and Zymelman, M. (1973) Los ciclos económicos argentinos. Bueno Aires: Paidós.

Diaz Alejandro, C.F. (1975). Ensayos sobre la historia económica argentina. Buenos Aires: Amorrortu editores.

Dosman, E. (2008) The Life and Times of Raul Prebisch, 1901-1986. Montreal and London: McGill-Queen's University Press

Dosman, E. (2001) Markets and the State in the evolution of the "Prebisch manifesto." CEPAL Review 75. Pp. 87-102.

Eichengreen, Barry. (1999). "The Keynesian Revolution and the Nominal

Revolution: Was There a Paradigm Shift in Economic Policy in the 1930s?" UC Berkeley working paper (March). http://www.econ.berkeley.edu/ eichengr/research/castronov.pdf

Fernandez López, M. (2002) Recepción del pensamiento de Pareto en Argentina. A AAEP 2002.

Fernandez López, M. (1996): "Ciclo económico periférico: los alumnos argentinos de Juglar", serie Seminarios, Buenos Aires,Instituto Torcuato Di Tella.

Ferns, H.S. (1950) "Investment and Trade Between Britain and Argentina in the Nineteenth Century”. The Economic History Review, New Series, Vol. 3, No.2. pp.203-218.

Ferns, H.S. "Britain's Informal Empire in Argentina, 1806-1914” Past \& Present, No.4. pp.6073.

Ferns, H.S. (1953) “Britain's Informal Empire in Argentina, 1806-1914” Past \& Present, No.4. pp.60-73.

Ferrer, A. (1996) La Economía Argentina. Buenos Aires: Fondo de Cultura Económica.

Ferreres, O.J. (2005) Dos siglos de economía argentina (1810-2004). Editorial El Ateneo: Buenos Aires.

Fisher, I. ([1911], 1985) The Purchasing Power of Money, New Jersey, Kelley Publishers.

Fiorito, L. (2001) John Maurica Clark's Contribution to the Genesis of the Multiplier Analysis. Università degli Studi di Siena. Dipartamento Di Economia Politica. Quaderni. N. 322 Maggio 2001. 
Fiorito, L. \& Vernengo, M. (2009) The Other J.M.: John Maurice Clark and the Keynesian Revolution. Journal of Economic Issues. Vol. 43. Number 4. Pp. 899-916

Ford, A.G. (1962) The Gold Standard 1880-1914. Britain and Argentina. New York: Oxford University Press.

Gesell, S. (1898) La anemia monetaria. Buenos Aires:n.p.

Gurrieri, A. (2001) “Las ideas del joven Prebisch.” Revista de la Cepal 75. Pp.69-82.

Haberler, G. ([1937], 1952) Prosperity and Depression. Geneva: League of Nations.

Hawtrey, R.G. ([1919], 1950) Currency and Credit. New York: Longmans, Green and Co.

Helleiner, E. (2009) "Central bankers as good neighbours: US money doctors in Latin America during the 1940s.” Financial History Review 16.1. pp. 5-25.

Helleiner, E. (2005) The Souther Side of Embedded Liberalism: The Politics of Postwar Monetary Policy in the Thirld World. TIPC Working Paper 01/5.

Irigoin, M.A. (2000) "Inconvertible paper Money, Inflation and Economic Performance in Early Nineteenth Century Argentina." Journal of Latin American Studies, Vol. 32, No.2. pp. 333-359.

Johns, M. (1992) "Industrial Capital and Economic Development in Turn of the Century Argentina.” Economic Geography. Vol. 68, No.2. Industrial Geography. Pp.188-204,.

Kahn, R. (1984) The Making of Keynes' General Theory. New York: Cambridge University Press,

Kahn, R. (1933) Appendix- Public Works and Inflation in Richard Kahn Selected Essays on Employment and Growth (1972). Cambridge: Cambridge University Press.

Kahn, R. (1931) The relation of home investment to unemployment in Richard Kahn Selected Essays on Employment and Growth (1972). Cambridge: Cambridge University Press.

Keynes, J.M. ([1923], 1971) A Tract of Monetary Reform. The Collected Writings of John Maynard Keynes. Vol. IV. New York: The MacMillan Press.

Keynes, J.M. (1933) The Means to Prosperity. The Collected Writings of John Maynard Keynes. Vol. IX. New York: The MacMillan Press.pp.335-366.

Keynes, J.M. ([1936] 1964) The General Theory of Employment, Interest and Money. New York: Harcourt Brace Jovanovitch Publishers.

King, J.(1998) "From Giblin to Kalecki: The Export Multiplier And the Balance of Payments Constraint on Economic Growth, 1930-1933." History of Economics Review. pp. 62-71. 
Kindleberger, Ch. and Aliber, R.Z.([1978], 2005) Manias, Panics and Crashes. New York: Palgrave Macmillan.

Kindleberger, Ch. (1984) A Financial History of Western Europe.Winchester: George Allen and Unwin.

Lavington, F. 1922. The Trade Cycle: An Account of the Causes Producing Rhythmical Change, London: P.S. King.

Leijonhufvud A. (1981) Information and Co-ordination. Oxford: Oxford University Press

Lorenzutti, J.A. (1996) Dinero, Política y Bancos. Historia del Banco Central de la República Argentina. 1935-1995. Buenos Aires: Ediciones Dunken.

Lorini, E. (1902) La Repubblica Argentina e i suoi maggiori problema di Economia e di Finanza. Vol. I. La QuestionIe Monetaria. Rome: E. Loeseher \& Co.

Lutz,V. (1955) " Multiplier and Velocity Analysis: a Marriage ", Economica, Vol. XXII, No. 85 , pp. 29-44.

Machlup, F. (1939) Period Analysis and the Multiplier Theory. Quarterly Journal of Economics. Vol. LIV. Pp. 1-27. Reprinted in Readings in Business Cycle Theory (1951). Illinois: Richard D. Irwin, Inc.

Mallorquín, C. (2007) "The unfamiliar Raúl Prebisch" in Ideas Policies and Economic Development in the Americas. Eds. Esteban Pérez Caldentey and Matías Vernengo. New York: Routdledge. pp. 98-122.

Mallorquín, C. (2006) Textos para el estudio del pensamiento de Raúl Prebisch. Cinta de Moebio. Marzo No. 025. Universidad de Chile. Santiago de Chile.

Mallorquín, C. (2005) Raúl Prebisch y el deterioro de la tesis de los términos de Intercambio. Revista Mexicana de Sociología. Año 67.No.2. pp.379-426.

Mallorquín, C. (1998) Ideas e historias en torno al pensamiento latinoamericano. Madrid: Plaza y Valdés.

Marichal, C. (2009) La crisis mundial de 1873 y su impacto en América Latina. El Colegio de México.

McCombie, J.S.L. and A.P. Thirlwall (1994): Economic Growth and the Balance-of Payments Constraint, New York, St. Martin's Press.

Morgan, V. (1965) The Theory and Practice of Central Banking 1797-1913. New York: Kelley Publishers. 
Nakamura, L. and Zaragaza, C.M. (2001) Banking and Finance in Argentina in the Period 190035. Federal Reserve Bank of Dallas. Working Paper No.01-7.

Nakamura, L. and Zaragaza, C.M. (1998) Economic Growth in Argentina in the Period 19001930: Some Evidence from Stock Returns. In John H. Coatsworth and Alan M. Taylor Eds. Latin America and the World Economy Since 1800. Cambridge: Harvard University Press. pp.247-267.

Newland, C. (1998). "Exports and terms of trade in Argentina, 1811-1870." Research Note. Bulletin Latin American Research. pp. 409-416.

Nurske, R. (1944) International Currency Experience. Lessons of the Inter-War Period. League of Nations.

O'Connell, A. (1984) Argentina into the Depression: Problems of an Open Economy in Rosemary Thorp Ed. Latin America in the 1930's. London: MacMillan Press.

O'Connell, A. (2001) The return of “vulnerability”and Raul Prebisch's early thinking on the Argentinean business cycle”. CEPAL Review 75. pp. 51-65.

Palma, J.G. (1987) "Prebisch, Raul" in The New Palgrave. A Dictionary of Economics. First Edition. Eds John Eatwell, Murray Milgate and Peter Newman. Palgrave MacMillan. pp.934-935

Paolera della, G. and Taylor A.M. (2001) Straining at the Anchor. Chicago: University of Chicago Press.

Paolera della, G. and Taylor A.M. (1998) Finance and Development in an Emerging Market: Argentina in the Interwar Period. In John H. Coatsworth and Alan M. Taylor Eds. Latin America and the World Economy Since 1800. Cambridge: Harvard University Press. pp. 139-169.

Panettieri, J. (1981) "La Ley monetaria de 1899 en el marco de formación de la Argentina Moderna" Desarrollo Económico, Vol. 21, No. 82. pp.231-256

Panettieri, J. (1980) "La Ley de Conversión monetaria de 1864 y la Oficina de Cambio e3 1867. Causas y Consecuencias económico-sociales”. Desarrollo Económico, Vol. 20, No. 79 pp.383412.

Pareto, V. (1896-1897). Cours D’Économie Politique. Tome Premier et Second. Paris: F. Pichon. Imprimeur-Editeur.

Pérez Caldentey, E. \& Vernengo M. (2007) A Tale of Two Monetary Reforms: Argentinean Convertibility in Historical Perspective Studi e Note di Economia Anno XII, n. 2-2007, pagg. 0722.

Potantiero, J.C. (1999) Juan B. Justo un fundador de la Argentina moderna. Fondo de Cultura Económica: Buenos Aires. 
Prebisch, R. (1993) Obras 1919-1949. Vol. IV Fundación Raúl Prebisch: Buenos Aires.

Prebisch, R. (1991) Obras 1919-1948. Vols. I to III Fundación Raúl Prebisch: Buenos Aires.

Prebisch, R (1984) Five Stages in My Thinking on Development in Pioneers in Development. Gerald Meier and Dudley Seers, Eds. (1984). Washington: World Bank. pp.175-191.

Prebisch, R. (1967) Hacia una Dinámica del Desarrollo Latinoamericano.Montevideo: Banda Oriental.

Prebisch, R. (1959) "Comercial Policy in the Underdeveloped Countries," American Economic Review. Pp.251-273.

Prebisch, R. (1951) “Interpretação do Processo de Desenvolvimiento Econômico”. Revista Brasilera de Economía.

Prebisch, R. (1950) “The Economic Development of Latin America and its Principal Problems” for the Economic Commission of Latin America, United Nations, Department of Economic Affairs. New York: Lake Success.

Prebisch, R. (1949) Economic Survey of Latin America. United Nations Economic Commission for Latin America. New York: United Nations.

Prebisch, R. (1943) La Moneda y el Ritmo de la Actividad Económica. Mimeo.

Prebisch, R. (1947) Introducción a Keynes. Buenos Aires: Fondo de Cultura Económica.

Peters, E.H. (1934) The Foreign Debt of the Argentine Republic. Baltimore: The Johns Hopkins Press.

Pollock, D., Kerner, D. and Love, J. (2002) Aquellos Viejos Tiempos: La Formación Teórica y Práctica de Raúl Prebisch en la Argentina. Un entrevista realizada por David Pollock. Desarrollo Económico, Vol. 41., No. 164. Pp. 531-553.

Pontoriero, G.A. Influencia de Raúl Prebisch sobre las políticas económicas aplicadas en la Argentina (1930-1986). X Encuentro de Cátedras de Ciencias Sociales y Humanísticas para las Ciencias Económicas (Paraná, 5 y 6 de junio de 2003). III Simposio sobre Desarrollo e Industrialismo.

Rock, D. (1987) Argentina 1516-1987. From Spanish Colonization to Alfonsín. Los Angeles: University of California Press.

Rosa, J.M. (1909) La Reforma Monetaria en la República Argentina. Buenos Aires: Imprenta y Casa Editora de Coni Hermanos.

Sanz-Villarroya, I (2006) "Economic Cycles in Argentina: 1875-1990." Journal of Latin American Studies, 38. pp.549-570. 
Sabato, H. (1983) "Wool Trade and Commercial Networks in Buenos Aires, 1840s to 1880s." Journal of Latin American Studies, Vol. 15, No.1. pp. 49-81.

Schumpeter, J.A. ([1939], 1969) Business Cycles. Philadelphia: Porcupine Press.

Sikkink, K. (1988) The Influence of Raul Prebisch on Economic Policy-Making in Argentina, 19501962. Latin American Research Review, Vol. 23, No. 2, pp 91-114

Simons, H.C. A Positive Program for Laissez Faire. Some Proposals for a Liberal Economic Policy. Public Pamphlet, 1934, No.15, ed. Harry D. Gideonse; reprinted in Simons, 1962.

Singer,H.W. (1987) "terms of trade and economc development" The New Palgrave. A Dictionary of Economics. First Edition. Eds John Eatwell, Murray Milgate and Peter Newman. Palgrave MacMillan. pp.626-628

Singer, H.W (1950) The distribution of gains between investing and borrowing countries" American Economic Review 40, pp473-485.

Stone, I (1977) "British Direct and Portfolio Investment in Latin America Before 1914." The Journal Of Economic History, Vol. 37, No3. pp.690-722.

Taussig, F.W. ([1911, 1915], 1946-47) Principles of Economics. New York: The McMillan Company.

Taussig, F.W. (1917) International trade under depreciated paper, a contribution to theory. Quarterly Journal of Economics 21 (May): 380-403.

Taussig, F. W. (1927). International Trade. New Jersey: Kelley Publishers.

Tobin, J. (1974) The New Economics. One Decade Older. New Jersey: Princeton University Press.

Tugan Baranowski ([1894], 1912) Las Crisis Industriales en Inglaterra. Madrid: Lopez Hoyos. R.

White, L.H. (2010) “Did Hayek and Robbins Deepen the Great Depression?" University of Misosouri. Mimeo.

http://economics.sbs.ohio-state.edu/jmcb/jmcb/07056/07056.pdf

Williams, J.H. (1920) Argentina International Trade Under Inconvertible Paper Money 18801900. New York: Greenwood Press Publishers. 